Article

\title{
Developing Flood Vulnerability Functions through Questionnaire Survey for Flood Risk Assessments in the Meghna Basin, Bangladesh
}

\author{
Islam M. Khairul ${ }^{1, *}+{ }^{\mathbb{D}}$, Mohamed Rasmy ${ }^{1}$, Miho Ohara ${ }^{1}$ and Kuniyoshi Takeuchi ${ }^{2} \mathbb{D}$ \\ 1 International Centre for Water Hazard and Risk Management (ICHARM) under the Auspices of UNESCO, \\ Public Works Research Institute (PWRI), Ibaraki, Tsukuba 305-8516, Japan; abdul@pwri.go.jp (M.R.); \\ mi-ohara@pwri.go.jp (M.O.) \\ 2 International Research Center for River Basin Environment, University of Yamanashi, Takeda, Yamanashi, \\ Kofu 400-8510, Japan; takeuchi@yamanashi.ac.jp \\ * Correspondence: k196wre@gmail.com or klwre96@yahoo.com; Tel.: +880-1719859366 \\ † Present address: Bangladesh Water Development Board, 72 Green Road, Dhaka 1205, Bangladesh.
}

check for updates

Citation: Khairul, I.M.; Rasmy, M.; Ohara, M.; Takeuchi, K. Developing Flood Vulnerability Functions through Questionnaire Survey for Flood Risk Assessments in the Meghna Basin, Bangladesh. Water 2022, 14, 369. https://doi.org/ 10.3390/w14030369

Academic Editors: Dawei Han and Lu Zhuo

Received: 2 December 2021 Accepted: 15 January 2022

Published: 26 January 2022

Publisher's Note: MDPI stays neutral with regard to jurisdictional claims in published maps and institutional affiliations.

Copyright: () 2022 by the authors. Licensee MDPI, Basel, Switzerland. This article is an open access article distributed under the terms and conditions of the Creative Commons Attribution (CC BY) license (https:/ / creativecommons.org/licenses/by/ $4.0 /)$.

\begin{abstract}
Flood vulnerability is estimated by Flood Damage Functions (FDFs), which are crucial for integrated flood risk assessment for developing sustainable flood management, mitigation, and adaptation strategies under global change. However, the FDFs, either empirical or synthetic, are not available in Bangladesh. Therefore, this paper focused on developing the synthetic type of FDFs for agriculture and rural households through the data of a well-structured questionnaire survey conducted in two pilot sub-districts of northeastern Bangladesh in the Meghna River basin. Multiple regression analyses were performed on the collected data, and the best performing models were selected to establish FDFs. The FDF for agriculture ( 196 samples) was developed concerning damage to Boro rice, whereas the FDFs for households ( $\sim 165$ samples) were developed concerning damage to the buildings and household property of three house types (Mud, Brick, and Concrete), separately. The results revealed that there were no yield losses when the water levels were lower than $25 \mathrm{~cm}$ ( rice tiller height), and the yield losses were $\sim 100 \%$ when the water levels were $70-75 \mathrm{~cm}$ deep ( rice grain height). Mud houses and their household property were found the most flood-vulnerable and likely to experience total damage when the water levels exceeded $150 \mathrm{~cm}$ above the plinth level, whereas the damage to Brick and Concrete houses and their household property was found likely to remain partial even when the water levels exceeded $150 \mathrm{~cm}$ above the plinth level. The developed FDFs can be used to assess potential flood risk in the study area for sustainable and effective management of flood disasters and build back better under global change in the future.
\end{abstract}

Keywords: northeastern Bangladesh; Meghna basin; flood risk assessment; damage curves; questionnaire survey; regression analysis

\section{Introduction}

Bangladesh is a deltaic country located at the confluence of three large transboundary rivers, the Ganges, Brahmaputra, and Meghna; however, about 92-93\% of their total catchment area is situated outside Bangladesh [1,2]. Due to this complex geographical location, flooding is the major and frequent natural hazard in Bangladesh, resulting in devastating damage to the people and socio-economic sectors of the country [3,4]. The northeastern part of the country, located downstream of the Meghna River basin, is suitable for agricultural and aquaculture activities. The area contributes to producing more than $18 \%$ of the nation's total rice grains and providing livelihoods for about 20 million people, thus supporting the country and its economy significantly [5-8]. However, this important area of the country is adversely affected by pre-monsoon (April-May) and monsoon (June-September) floods every year. Particularly, frequent pre-monsoon flash floods 
damage the area in April and May due to heavy rainfall occurring in the foothills of the Meghalaya Mountain range (the rainiest places of the world) near the Bangladesh-India border [9]. Moreover, tidal and/or backwater effects that are prolonged during flooding cause heavy damage to the area [4,10-12]. Additionally, floods in northeastern Bangladesh are expected to increase due to climate change, making the area even more hazard-prone in the future [11,13-17]. Therefore, flood disaster management in the area is among the country's top priorities to ensure the food security of the nation. However, effective and timely management of flood disasters requires practical flood risk assessment that can assist decision makers in drawing effective and sustainable disaster risk reduction policies [18-21].

Flood risk assessment is an important tool to evaluate possible benefits and consequences of a flood [22,23]. It can, thus, play an essential role in managing and mitigating flood disasters and allotting resources to activities such as preparation, rescue, investment, restoration, and reconstruction [24]. Flood risk assessment mainly involves three components: assessment of flood hazard, flood vulnerability, and flood exposure [25-27]. Flood hazards are usually estimated using flood depth, duration, and extent, which are commonly obtained through hydrological model simulation using rainfall data. However, hydrological modeling of the Meghna River basin is difficult because more than $60 \%$ of the basin is located in India, and no reliable transboundary rainfall data are available for hydrological simulation. To address this limitation, the authors previously developed a reliable gridded rainfall dataset by combining locally available ground data and globally available satellite data, exclusively for the Meghna River basin, and verified the dataset by simulated river discharges at two locations of the basin [28].

The second component of flood risk assessment is the estimation of flood vulnerability. It is usually estimated by flood damage functions that are derived by correlating flood hazard characteristics with damage [29-31]. More specifically, flood damage functions define a relationship between inundation depth and economic damage for a particular type of land use (e.g., agriculture) or structure (e.g., house buildings); hence, they are also called stage-damage functions $[18,20,25,32]$. These functions can be categorized into two types: empirical and synthetic. Empirical flood damage functions are developed using actual damage data, whereas synthetic damage functions are developed based on damage data collected through questionnaire surveys $[18,21]$. The development of empirical damage functions is a difficult task in Bangladesh, unlike in many developed countries, since actual flood damage data recorded by the country's different agencies are limited, inconsistent, and fragmented. Therefore, the development of synthetic flood damage functions is an alternative in Bangladesh. However, flood vulnerability estimation using synthetic functions has not yet received much scientific attention in Bangladesh and remains a challenge. This paper, thus, aims to develop synthetic flood damage functions for agriculture and rural households through a questionnaire survey conducted in the northeastern part of Bangladesh.

Many researchers and government agencies worldwide have attempted establishing flood damage functions via questionnaire surveys for areas of different content characteristics and accordingly established stage-damage relationships of various damage categories (e.g., agricultural or residential damage) to assess flood risk [20,21,27,31,33-39]. For the assessment of flood risk, some researchers used depth-damage functions obtained from other countries when their study areas bore similar regional content characteristics [31,37-39]. None of the above studies bear similar regional content characteristics (e.g., seasonality of floods, flood types, flood timing and duration, lead time, topography, land cover, crop type, livelihood, etc.) to the areas of Bangladesh. Hence, the depth-damage curves established by the above researchers are not likely applicable or spatially transferrable for flood risk assessment in Bangladesh. In Bangladesh, a few researchers attempted to calculate the potential flood risk in urban areas (mainly in Dhaka City) by assuming vulnerability as proportional to the population density or by calculating vulnerability as indices assuming several weight factors according to land use classes [40-42]. One study [43] developed a 
rule-based computerized decision support system to simulate rice yield loss through a crop simulation model for monsoon flooding (June-September) in Bangladesh. The main constraint of the study is that the model was run with site-specific input data, and, thus, a national minimum dataset is required to support decision making. Another limitation is that it only considered rice crops cultivated during the monsoon period in the region of Bangladesh different from the rice crops and region considered in this study. In addition, the validation of the simulated rice yield loss was not performed and, thus, the results are likely to have uncertainties. Two recent studies [44,45] conducted for flood risk assessment in the eastern part of Dhaka also estimated vulnerability by assuming land use-based weight factors or using stage-damage relationships obtained from several other studies. The fact is, in Bangladesh, no regional-scale damage functions with identical content characteristics exist, and, thus, establishing such functions on a local scale is necessary. Therefore, as a first attempt, this study established a synthetic type of flood damage functions for agriculture and rural households through the data of a structured questionnaire survey conducted in the two sub-districts of the northeastern region of Bangladesh for assessing potential flood risk in the region.

\section{Study Area}

The northeastern part of Bangladesh, located downstream of the Meghna River basin, was chosen for this study. The Meghna River originates in the Meghalaya and Manipur Mountain chains of India and flows down to agriculture-dominated northeastern Bangladesh (Figure 1a). The basin topography in Bangladesh is characterized by relatively flat plains comprising mostly cropland and paddy fields and gentle hills [46,47]. The Barak River, the main source of the Meghna River, bifurcates into the Surma and Kushiyara Rivers at the Amalshid point near the Bangladesh-India border (Figure 1a). Discharges from steep and highly flashy rivers (e.g., the Lubachara, Jadukata, and Chela Rivers) originating in the Khasi and Jaintia Hills, the wettest places in the world with an annual average rainfall of about 12,000 mm [9,10], contribute to the Surma River through its right bank. On the other hand, the Kushiyara River receives water from the rivers that originate in the Tripura Hills (e.g., the Manu and Khowai Rivers).
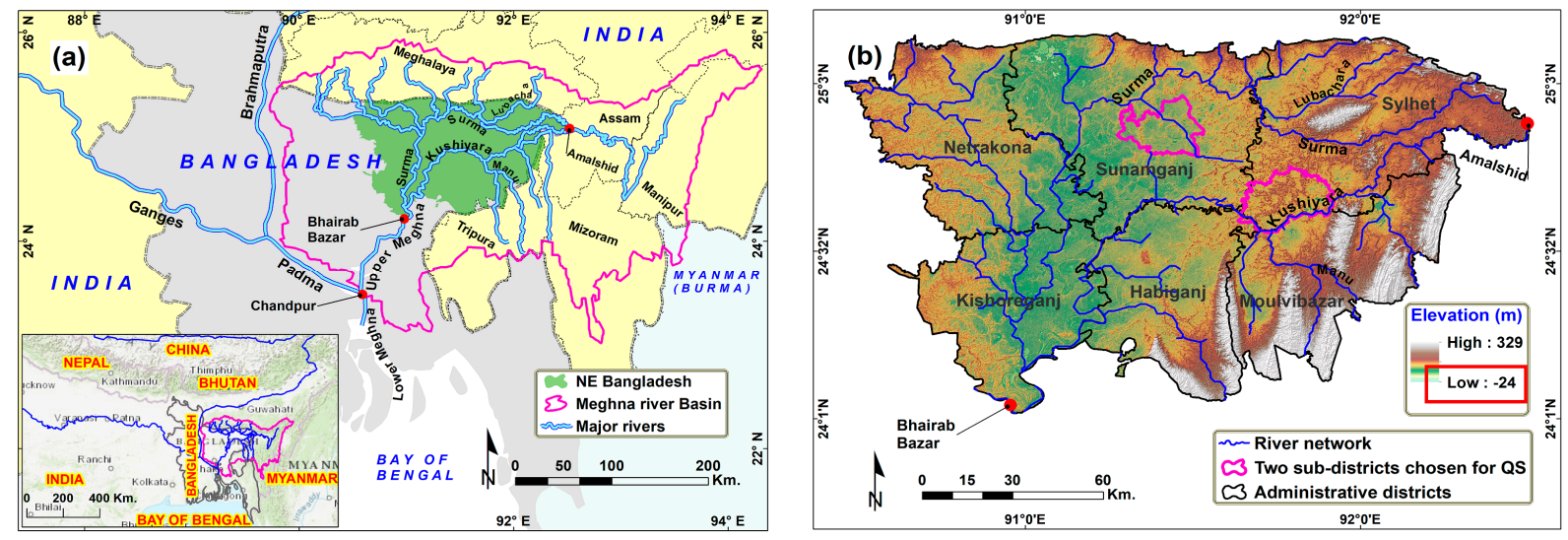

Figure 1. Salient features of the study area. (a) The Meghna River basin, showing the major rivers entering into Bangladesh from India, joining the Padma River at Chandpur, and flowing down to the Bay of Bengal, and also showing northeastern (NE) Bangladesh inside the Meghna basin (shaded green); (b) the topography of northeastern Bangladesh, which shows the river system and chosen sub-districts for a questionnaire survey (QS).

The study area, consisting of six administrative districts, mainly lies in the SurmaKushiyara river system (Figure 1b). Between the Surma and Kushiyara Rivers there are many low-land regions, internal draining depressions (locally called Haors), meandering flood channels, and abandoned river courses, which get flooded in every pre-monsoon 
(April-May) and monsoon (June-September) season. Many Haors (about 423), which are typical wet- and low-lands in Bangladesh, are located in this region, and most of them remain inundated for about 4-7 months a year. Thus, people of this area can cultivate one crop a year, which is a type of rice locally called Boro rice. Unfortunately, almost every year, the rice fields are affected just about a month before the harvesting time (at the time of the rice's flowering through maturity stage) by pre-monsoon floods, causing immense socio-economic losses to the nation. In 2017, a massive pre-monsoon flash flood devastated the study area, affecting about 1 million people and one-third of the households. The flood exceeded the danger levels at various locations of both the Surma and Kushiyara Rivers, inundating vast areas of rice fields. The Department of Disaster Management, Bangladesh reported that 219,840 hectares of crops, mainly Boro rice at the nearly-readyfor-harvesting stage, were damaged. Moreover, nearly 776,579 households were affected, with approximately 30,000 of them fully or partially destroyed [48,49].

Two administrative sub-districts of the study area (namely, Dakkhin Sunamganj and Balaganj in Figure 1b) were selected to conduct the aforementioned questionnaire survey to collect flood damage data of three damage classes (i.e., Boro rice, house building, and household property). The main reasons for selecting the two sub-districts are: (1) Boro rice and households of the sub-districts were affected and damaged in a larger quantity during the recent 2017 flood [48]; (2) since the study area is surrounded by two independent rivers (i.e., Surma and Kushiyara), one sub-district each was chosen from these two river basins; and (3) three types of house buildings are seen in the study area [50]. However, the houses in the Dakkhin Sunamganj sub-district are mainly a mud type $(\sim 81 \%)$, whereas those in the Balaganj sub-district consist of all three types proportionately [50]. Therefore, to get more generalized results, these two sub-districts were selected.

\section{Methods}

Figure 2 shows the flowchart of the methodology used in this study. The methodology consisted of the following steps: (1) Conducting a well-structured questionnaire survey in the chosen sub-districts to collect flood damage data based on the calculated minimum sample size for the three damage classes (i.e., Boro rice, house building, and household property); (2) Investigating the similarity and variations of the collected datasets between the two sub-districts for each damage category; (3) Evaluating the consistency of the collected data statistically for each damage category; (4) Performing multiple regression analyses with the data to fit the depth-damage relationship for each damage category; and (5) Identifying the best regression function based on several performance indicators to establish damage curves for the mentioned damage classes.

\subsection{Outline of the Questionnaire Survey}

During flooding periods, the people of the study area mainly experience losses of their nearly-ready-for-harvesting Boro rice and their houses with household property [48,49]. The Bangladesh Bureau of Statistics and the Department of Disaster Management, Bangladesh, reported that only Boro rice fields, households, and livestock were affected by the 2017 flood $[48,50]$. No other private and public property damage (e.g., local road damage, embankment damage) was stated in the report. No casualties were reported as well. Additionally, during the past floods of 2004, 2010, and 2016, damage to Boro rice and households was only reported by the Bangladesh Bureau of Statistics [50]. Given those reports, the damage to Boro rice and households was found as a major concern for the government and policy makers to draw a roadmap for sustainable development in the study area. Therefore, the three damage classes of Boro rice, house building, and in-house property were considered in this study to conduct the aforesaid questionnaire survey. Since Boro paddies at their flowering through maturity stage are usually damaged by pre-monsoon flash floods in the month of April, just 20-30 days before harvesting time, the maturity stage ('flowering through maturity stage' is termed as 'maturity stage') of the rice was only considered for the survey. 


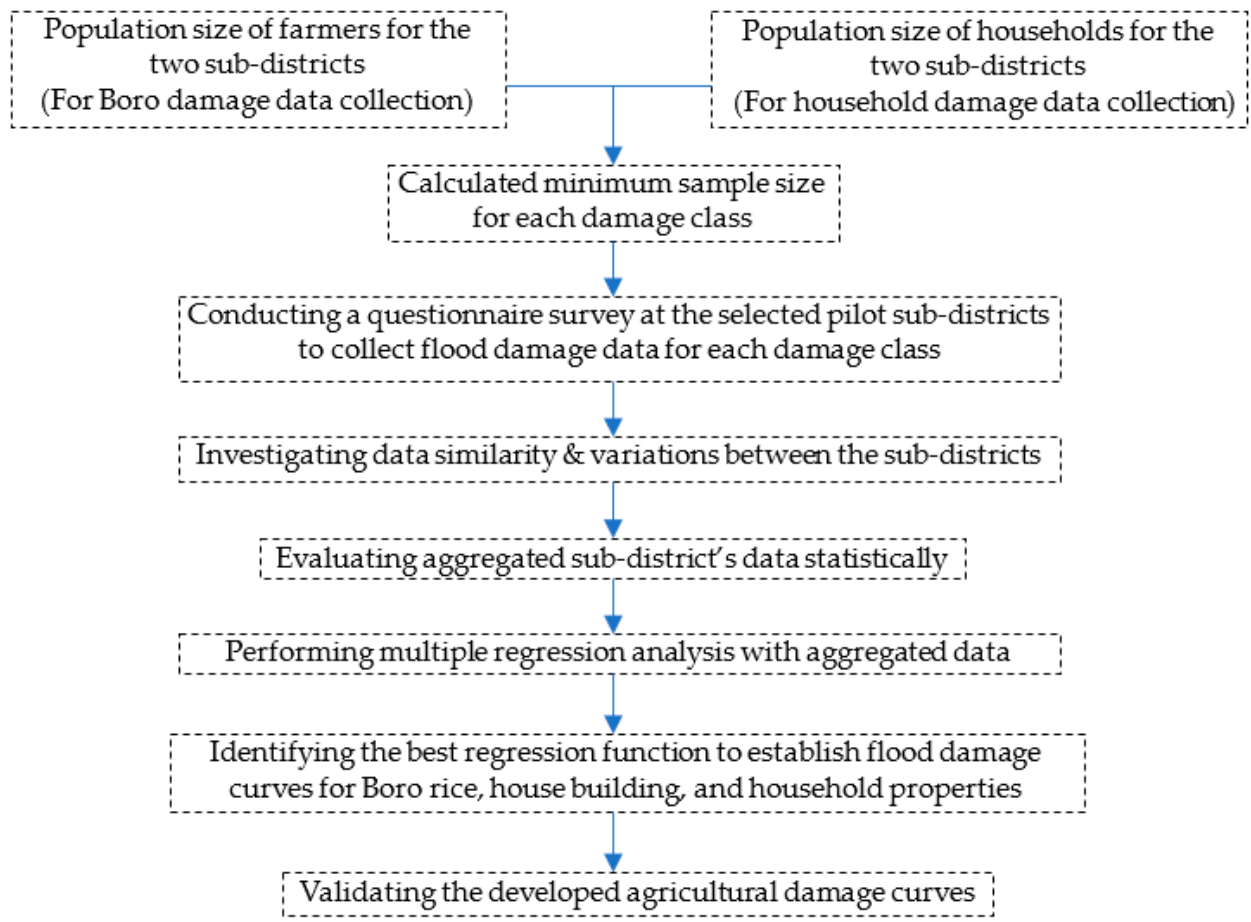

Figure 2. Flowchart of the methodology used in this study to develop synthetic flood damage functions for agriculture and rural households of northeastern Bangladesh located downstream of the Meghna River basin.

Before the ground survey, the minimum representative sample size for each damage category (i.e., samples of farmers for Boro rice damage and households for house and property damage) was calculated using a probability sampling technique [51]. Using this technique, a population size of farmers with more than 0.05 acre of operating land and that of households comprised of at least two members were obtained from the Bangladesh Bureau of Statistics for the two selected sub-districts. The obtained population sizes were 39,941 for farmers and 86,279 for households, respectively [50]. Using a confidence level of $90 \%$, a margin of error of $6 \%$ for farmers and $6.5 \%$ for households, and considering a response rate of $50 \%$, the targeted minimum sample sizes were calculated. They were 188 for farmers and 160 for households, respectively. The actual number of samples collected in the field during the questionnaire survey were 196 for farmers and 165 for households, respectively. Therefore, the surveyed dataset for this study can be considered sufficient and reliable. Table 1 shows the total population size and calculated and collected sample sizes by sub-district. The samples of the questionnaires designed to collect Boro-rice and household damage data are presented in Appendices A and B, respectively.

Table 1. Total population size, calculated minimum sample size, and size and percentage of collected samples for farmers and households by sub-district.

\begin{tabular}{|c|c|c|c|}
\hline \multirow{2}{*}{ Item } & \multirow{2}{*}{$\begin{array}{c}\text { Sample } \\
\text { Class }\end{array}$} & \multicolumn{2}{|c|}{ Sub-Districts } \\
\hline & & Dakkhin Sunamganj & Balaganj \\
\hline \multirow{2}{*}{ Population size } & Farmers & \multicolumn{2}{|c|}{39,941} \\
\hline & Households & \multicolumn{2}{|c|}{86,279} \\
\hline \multirow{2}{*}{$\begin{array}{l}\text { Calculated minimum } \\
\text { sample size }\end{array}$} & Farmers & \multicolumn{2}{|c|}{188} \\
\hline & Households & \multicolumn{2}{|c|}{160} \\
\hline \multirow{2}{*}{$\begin{array}{l}\text { Collected sample } \\
\text { Size }\end{array}$} & Farmers & 131 & 65 \\
\hline & Households & 67 & 98 \\
\hline \multirow{2}{*}{$\begin{array}{c}\text { Percentage of } \\
\text { collected samples (\%) }\end{array}$} & Farmers & 66.84 & 33.16 \\
\hline & Households & 40.60 & 59.40 \\
\hline
\end{tabular}


The survey to collect flood damage data for each of the target classes was conducted by the first author for 12 days (25 November to 6 December 2018); 7 days in the Dakkhin Sunamganj sub-district of the Sunamganj district and 5 days in the Balaganj sub-district of the Sylhet district. As depicted in Table 1, Boro-rice and household damage data were collected, respectively, from 131 farmers and 67 households in the Dakkhin Sunamganj sub-district. On the other hand, the total samples collected in the Balaganj sub-district for Boro rice and household damage were 65 and 98, respectively. An average of 30 samples was collected each day from dawn to dusk by spending an average of 15-20 min per sample. An average of 5 min was spent to make the questionnaire understandable for the respondents, and the remaining time was used to collect answers to the questions.

Three employees (sub assistant engineers and surveyors) from the Bangladesh Water Development Board (BWDB; https: / / www.bwdb.gov.bd/, accessed on 10 January 2022) constantly supported the first author in conducting the survey. Every morning, the Boro damage survey was first conducted at a local village Bazaar (marketplace) by gathering 5 to 10 farmers. The farmers were notified beforehand to gather in such a place with the help of the BWDB staff. An average of $\sim 30 \%$ Boro damage samples were collected from this kind of gathering. The remaining $\sim 70 \%$ samples were collected from individual farmers by moving from one village to another. While collecting Boro damage data from individual farmers and households in a village and paddy fields, household damage data (damage to house buildings and in-house property) were also collected at the same time. Sometimes the same individuals answered questions about both Boro rice damage and household damage. All of the respondents who answered the questionnaires of Boro damage were male; only about $5 \%$ of the respondents who answered the household damage questionnaires were female. Almost all of the respondents were of 30-50 years of age.

It is worth mentioning that about 2 months before the actual survey, draft questionnaires were prepared by the authors and sent to the BWDB employees to carry out discussions with farmers and households as to whether the questions in the draft questionnaires were understandable to the respondents. The BWDB staff went to sample areas, where 60 potential farmers and households (30 for each sub-district) were randomly selected and directly asked to discuss the draft questions to examine actual responses. From such discussions, the recommendations and corrections made by the respondents over the draft questionnaires were collected by the BWDB staff and sent back to the authors to consider them for improvements. Based on the obtained feedback, the design of the sample questionnaires was finalized by making them easily understandable for respondents and accordingly used in the actual questionnaire survey. During the actual survey, all the questions in the questionnaires were asked to the respondents by the first author with the help of the BWDB staff, and the answers were written down mostly by the first author. No questionnaire was given to the respondents to answer the questions by themselves. In such a way, the subjectivity of the respondents was significantly avoided in the questionnaire survey, which increased the accuracy of the survey [52].

In this study, the questionnaire survey was mainly conducted considering the recent 2017 flood. However, the sample questionnaires also included some comprehensive questions for other floods, such as ones in 2004, 2010, 2016, and 2018 (refer to Appendices A and B). However, during the survey, the respondents seemed to have difficulty answering the questions related to flood depths, duration, and damage for the flood years of 2004, 2010, and 2016. Due to their forgotten memory, most of the respondents could not provide adequate information on flood depths, duration, and damage to Boro rice and households for the floods of 2004, 2010, and 2016. However, the respondents were able to recall such information about the recent 2017 flood and answer the questions. Therefore, the damage data (considering flood depths and duration) collected for each damage class via the questionnaire survey in this study were based on the 2017 flood. 


\subsubsection{Boro Rice Damage Survey}

Boro rice is the major crop of the study area, usually planted in mid-December to early January and harvested by late April [53,54]. Flood damage to Boro rice usually takes place in its flowering through maturity stages, just about a month before the harvesting time. Therefore, in the questionnaire survey, other growth stages of the rice were not included and only the maturity stage of the rice was considered. In this study, a total number of 196 flood-affected farmers were interviewed to collect Boro damage data. Each interviewee was requested to answer the reduced amount of rice yield in terms of varying flood depth and duration, particularly during the 2017 flood. During the survey period, many other data were also collected, including the standard height of Boro paddies, the average expected yield per unit area, and the value per unit weight. Refer to Appendix A for the sample questionnaire.

\subsubsection{Household Damage Survey}

The household damage survey was conducted for house building and household property damage. Classifying households by type, age, and social status is the primary step of undertaking such a survey [25]. The Bangladesh Bureau of Statistics groups the households of the study area into three classes according to their building materials [50]. They are shown in Figure 3a-c and are called (a) Mud houses (locally called Kaccha), (b) Brick houses (locally called Semi-Packa), and (c) Concrete houses (locally called Packa). It is worth mentioning that the majority of houses observed in the study area were Mud-type, one-story houses.

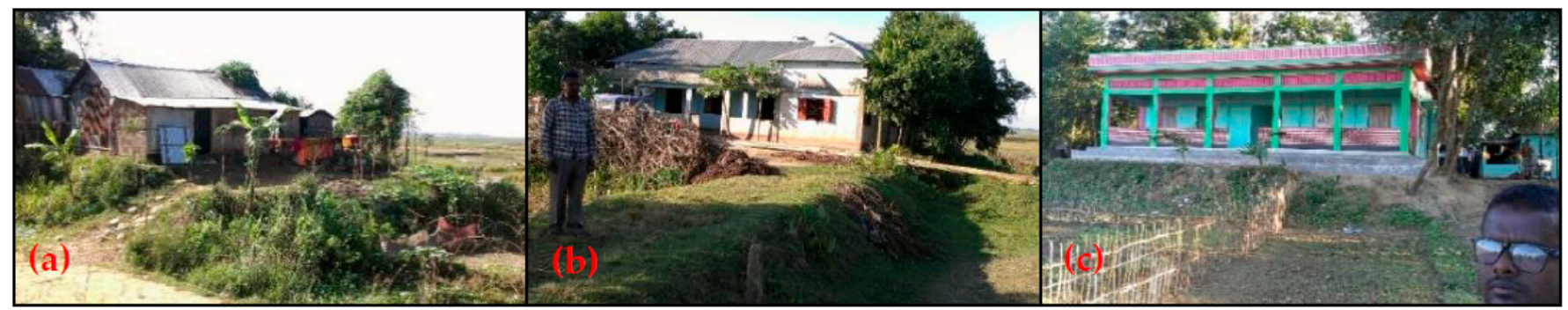

Figure 3. Types of houses shown in the study area according to building materials. (a) Mud: made of mud, soil, straws, bamboo sticks, jute sticks, and corrugated iron sheets; (b) Brick: made of mud and/or cement, bricks, and corrugated iron sheets; (c) Concrete: made of bricks, cement, brick chips and/or stone chips, and steel rods.

During the survey, the damage to house buildings was calculated considering the repairing and/or reconstruction costs of flood-damaged or destroyed houses. On the other hand, the damage to rice stocked up inside the house, furniture, kitchen items, appliances, clothes, radios, televisions, and other household goods was considered for household property damage estimation. A total of 165 flood-affected households were interviewed to gather information on the damage to houses and household property according to varying flood inundation depths, considering mainly the duration of both pre-monsoon and monsoon floods. Several other questions, such as the average building value of each type of house, the plinth levels (floor height from the ground level) of houses, and the accumulated value of the household property, were also asked at the time of the household damage survey. Since the collected data were based on the recent past floods, it was assumed that the respondents were like to have clear picture on the damage data of the house and household property. Refer to Appendix B for the sample questionnaire.

\subsection{Development of Flood Damage Functions}

The collected data were used to establish damage functions for the target damage classes. Damage data on Boro yield were collected as per the local measurement unit called Maund per Bigha (equivalent to $330 \mathrm{~kg}$ per hectare). As suggested by several 
researchers [21,27,31,37-39], Boro yield damage data were converted into relative terms as percent damage using Equation (1), to make them clear for all readers and applicable to different times and spaces.

$$
P R D_{i}=100 * R R Y_{i} / M E Y
$$

where $P R D_{i}$ is the percent rice yield damage for sample $i, R R Y_{i}$ is the reduced rice yield due to flood inundation for sample $i$, and $M E Y$ is the maximum expected rice yield with no inundation.

The house and household property damage data, on the other hand, were collected in thousand Bangladesh currency (Bangladesh Taka = BDT). In this study, to make it independent of changes in market values and make it applicable to different times and areas, the damage to houses and household property was normalized and expressed in percent damage using the following equations, as also suggested by [20,55]:

$$
\begin{gathered}
\text { PHD }_{i, j}=100 * H D V_{i, j} / H V_{i, j} \\
P_{P P D_{i, j}}=100 * H P D V_{i, j} / H P V_{i, j}
\end{gathered}
$$

where $P H D_{i, j}$ and $P H P D_{i, j}$, respectively, are the percent house damage and percent household property damage for house type $i$ and sample $j, H D V_{i, j}$ is the house building damage value, $H V_{i, j}$ is the house building value, $H P D V_{i, j}$ is the in-house property damage value, and $H P V_{i, j}$ is the total in-house property value for house type $i$ and sample $j$.

With the collected data, regression analyses were performed to establish flood damage functions (or depth-damage relationships), as suggested by many researchers $[21,27,35,56]$. Five regression models were used in this regard, as shown in Table 2.

Table 2. Names and equations of the regression models used in this study.

\begin{tabular}{cc}
\hline Regression Models & Equations of Functions \\
\hline Linear & $y=a+b x$ \\
Logistic & $y=a /\left(1+b e^{-c x}\right)$ \\
Natural Logarithm & $y=a+b \ln (x)$ \\
Polynomial (3rd order) & $y=a x^{3}+b x^{2}+c x+d$ \\
Power & $y=a x^{b}$ \\
\hline
\end{tabular}

$y=$ dependent variable $=$ Damage of Boro rice, house building, and household property; $x=$ Independent variable $=$ Depth of inundation; $a, b, c$ and $d$ are parameters of the functions.

To evaluate the performance of the models and identify the best one, four indicators, i.e., the Coefficient of Determination (CD), Correlation Coefficient (CC), Standard Error (SE), and Akaike's Information Criterion (AICC), were used. A perfect model should have the CC and CD indices of 1 . In addition, the lower the SE and AICC indices, the better the model performance.

\section{Results and Discussions}

\subsection{Development of Agricultural Damage Curves}

The agricultural damage curve for Boro rice was developed in this study using the survey data. The data revealed that the average height of the Boro paddies is about $85 \mathrm{~cm}$, and its initial flood damage usually starts after 2-3 days of inundation at a depth of about $30 \mathrm{~cm}$. Some characteristics of Boro rice revealed from the survey are depicted in Table 3.

Table 3. Characteristics of Boro rice in the sample area.

\begin{tabular}{ccccc}
\hline Rice Type & Average Height $\mathbf{( c m )}$ & $\begin{array}{c}\text { Max. Expected } \\
\text { Yield } \\
\text { (MT/Hectare) }\end{array}$ & $\begin{array}{c}\text { Depth at which } \\
\text { Flood Damage } \\
\text { Starts (cm) }\end{array}$ & $\begin{array}{c}\text { Duration at } \\
\text { which Flood } \\
\text { Damage Starts } \\
\text { (Day) }\end{array}$ \\
\hline Boro & 85 & 4.95 & 30 & $2-3$ \\
\hline
\end{tabular}


During the survey, information on Boro yield damage was collected in the two subdistricts, considering varying flood depths of 30,45,60,75, and $90 \mathrm{~cm}$ and flood durations of $1-3,4-7$, and more than 7 days. To investigate data variability between the sub-districts, the damage data collected for each sub-district (i.e., 131 samples for Dakkhin Sunamganj and 65 for Balaganj) were compared using four statistical indices (mean, median, mode, and standard deviation). This comparison was performed for each set of flood duration and is shown in Figure $4 \mathrm{a}-\mathrm{c}$. The results showed only slight variability between the datasets of the sub-districts according to the four indices. This might be because the topography, land use, households, and people's livelihoods in the study area are very similar. It, thus, suggests that the damage curves that this study attempted to develop for Boro rice, can be used for flood damage and risk assessment not only in the pilot sub-districts but also in other regions of similar characteristics.
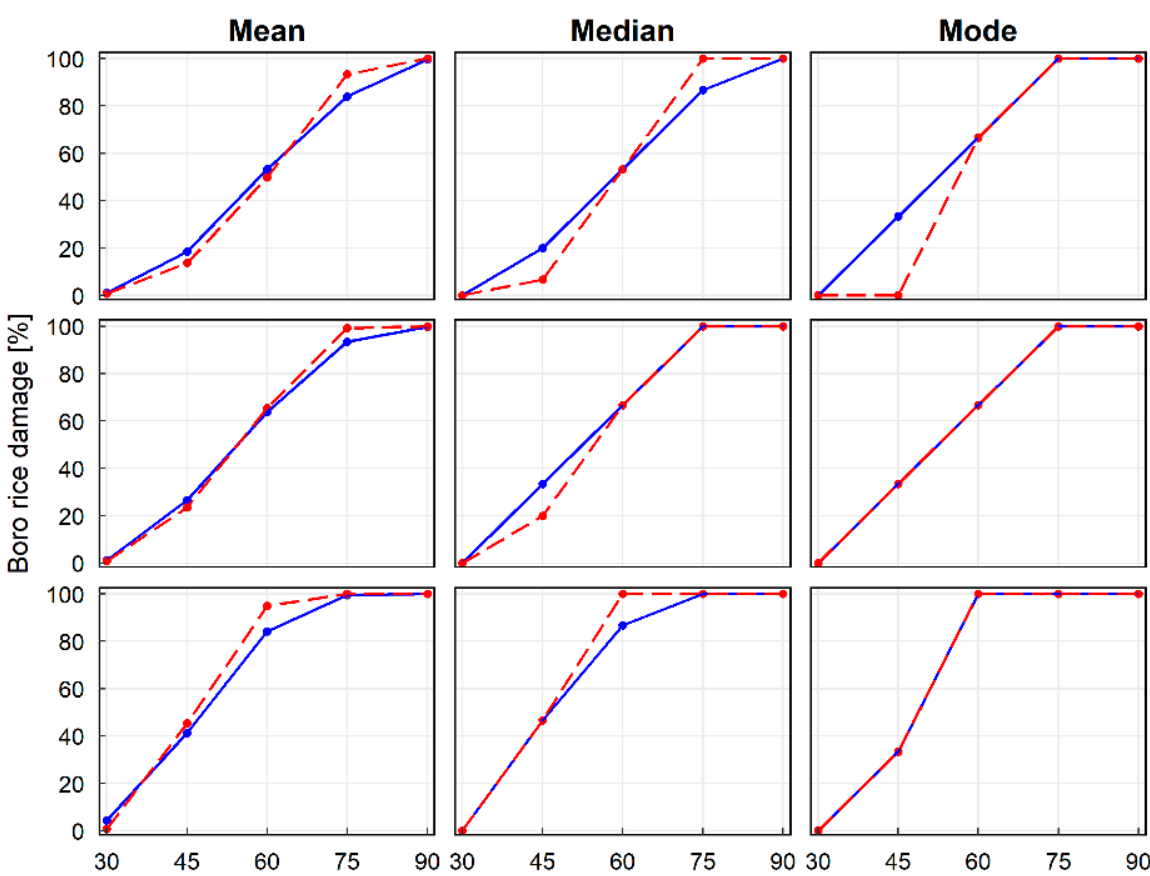

Standard Dev.
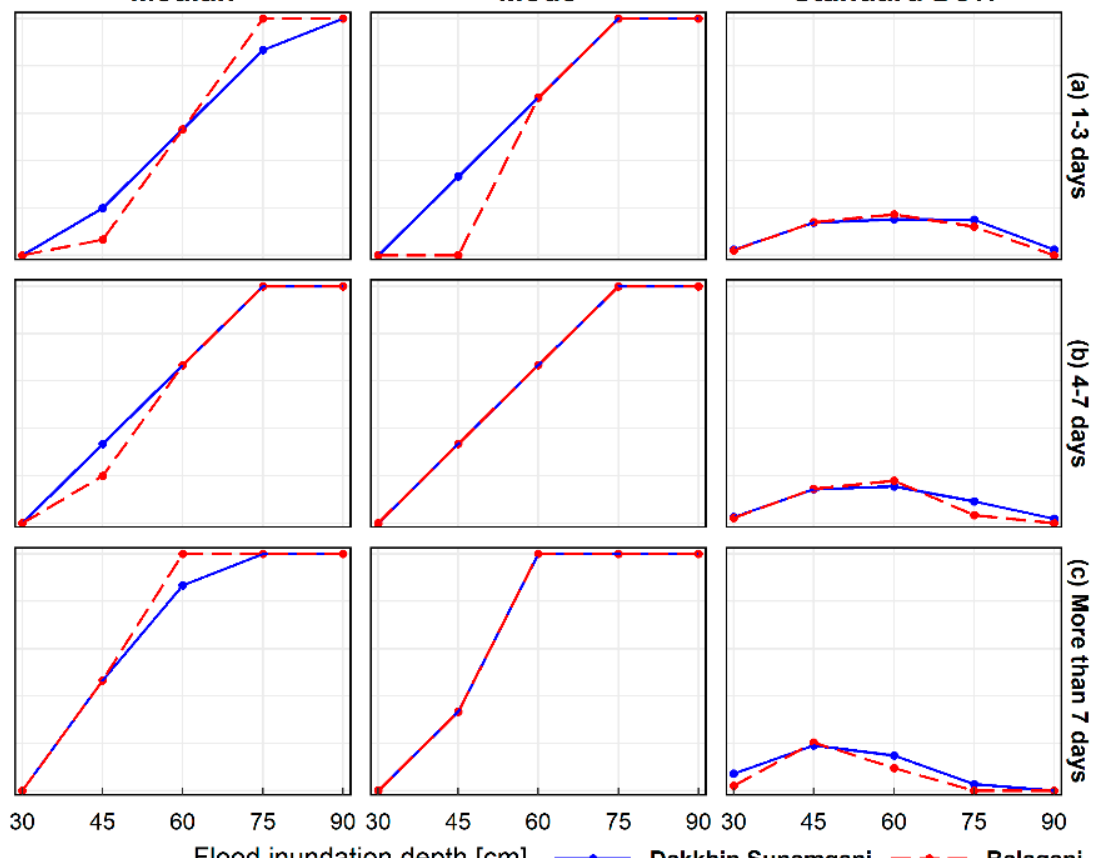

Flood inundation depth [cm]

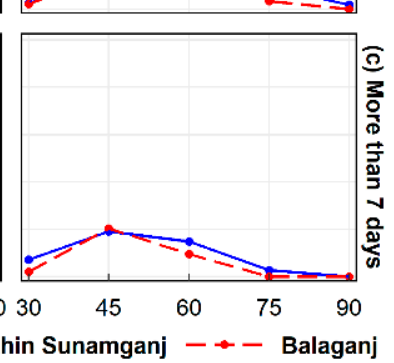

Figure 4. Comparison between the collected datasets of the two sub-districts using four statistical indices for the selected flood durations of (a) 1-3 days, (b) 4-7 days, and (c) more than 7 days.

To depict the relationship between Boro yield loss and flood depths, box and whisker plots were plotted with the aggregated datasets of the two sub-districts (i.e., 196 samples) for each set of the selected flood durations. The plots are shown in Figure 5a-c. Several statistics of the datasets, such as the mean, median, mode, and standard deviation, are also drawn in the figure.

The Boro yield loss at depths of 45,60 , and $75 \mathrm{~cm}$ showed larger variability in the data for the flood duration of 1-3 days (Figure 5a). The same variability for the depths of 45 and $60 \mathrm{~cm}$ was also shown in the case of a flood that lasted more than 7 days (Figure 5c). However, the data for a 4-7 day flood showed minimum variations (an average of $8 \%$ ) in yield loss at all depths of inundation (Figure $5 b$ ). The variability shown in the data might be due to the effect of selecting several days on a single set of flood duration. This might also be caused by the interviewee's responses that are subject to their individual experiences and memories related to flood damage. Although variability and inconsistency were somewhat observed in the collected data, their standard deviations $(\sigma)$ were obtained as reasonably small in quantity (an average of $9 \%$ ) for each range of duration (Figure 5a-c, purple-colored line), which indicates satisfactory reliability of the collected data. Regression analyses were, thus, performed with the data using five models to establish a best-fit relationship between 
Boro damage and flood depths for each range of flood duration. The results of the regression analyses are provided in Table 4 .
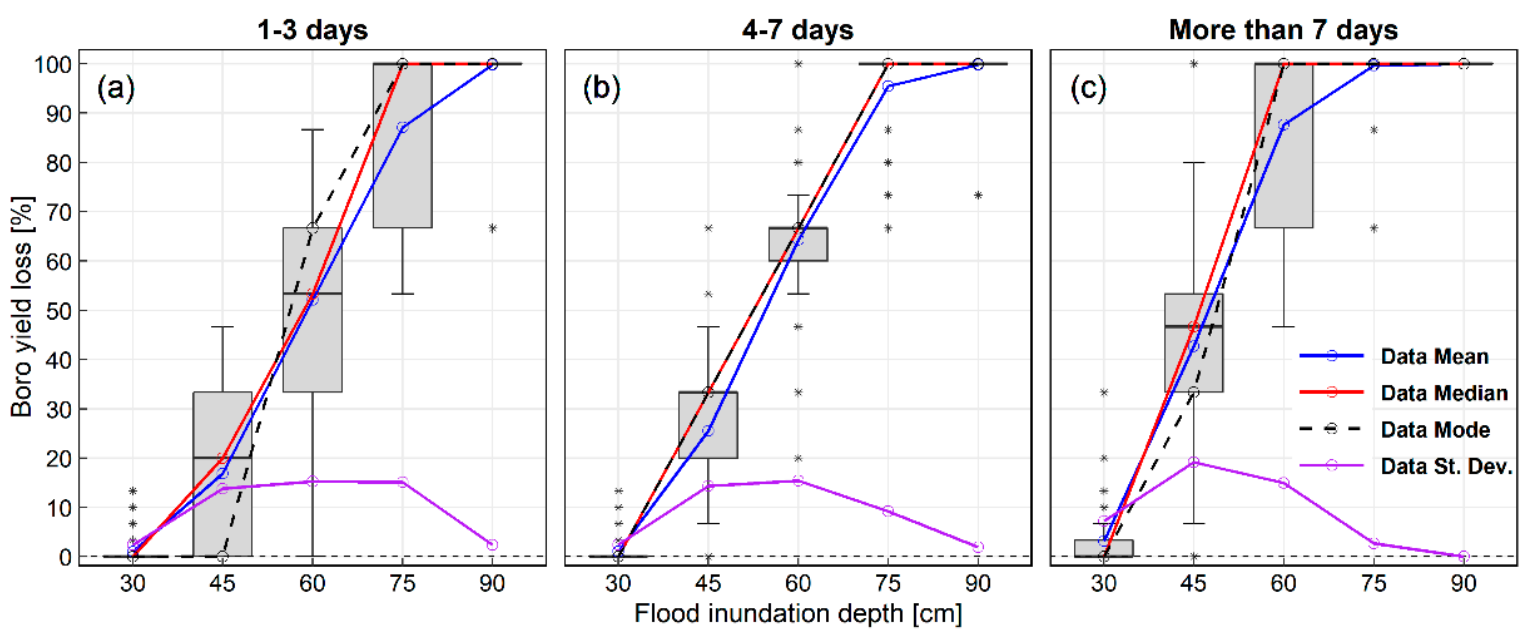

Figure 5. Distribution of Boro yield loss against selected flood depths for 196 samples, presented in box and whisker plots for the flood durations of (a) 1-3 days, (b) 4-7 days, and (c) more than 7 days. Asterisks are the outliers of the data. Outliers are located outside the whiskers of the plot.

Table 4. Results of five regression models performed with 196 collected samples of Boro yield damage.

\begin{tabular}{|c|c|c|c|c|c|c|c|c|c|c|}
\hline \multirow{2}{*}{$\begin{array}{l}\text { Regression } \\
\text { Models }\end{array}$} & \multirow{2}{*}{$\begin{array}{c}\text { No. of } \\
\text { Samples }\end{array}$} & \multirow{2}{*}{$\begin{array}{c}\text { Flood } \\
\text { Duration }\end{array}$} & \multicolumn{4}{|c|}{ Value of Parameters } & \multirow{2}{*}{ SE } & \multirow{2}{*}{$\mathrm{CC}$} & \multirow{2}{*}{$\mathrm{CD}$} & \multirow{2}{*}{ AICC } \\
\hline & & & a & $\mathbf{b}$ & c & d & & & & \\
\hline \multirow{4}{*}{ Linear } & \multirow{4}{*}{196} & $1-3$ days & -55.77551 & 1.78594 & - & - & 12.98 & 0.95 & 0.90 & 5024.65 \\
\hline & & 4-7 days & -49.78231 & 1.78367 & - & - & 13.20 & 0.94 & 0.89 & 5057.18 \\
\hline & & Above 7 days & -33.66327 & 1.67166 & - & - & 18.01 & 0.89 & 0.80 & 5666.35 \\
\hline & & 1-3 days & 102.6640 & 943.202 & 0.114664 & - & 11.60 & 0.95 & 0.91 & 4803.59 \\
\hline \multirow[t]{2}{*}{ Logistic } & \multirow[t]{2}{*}{196} & 4-7 days & 102.1564 & 807.565 & 0.121528 & - & 10.62 & 0.97 & 0.93 & 4631.30 \\
\hline & & Above 7 days & 99.83938 & 2356.29 & 0.165006 & - & 11.52 & 0.96 & 0.92 & 4791.76 \\
\hline \multirow{3}{*}{$\begin{array}{c}\text { Natural } \\
\text { Logarithm }\end{array}$} & \multirow{3}{*}{196} & $1-3$ days & -336.0498 & 96.2824 & - & - & 14.44 & 0.93 & 0.87 & 5233.51 \\
\hline & & 4-7 days & -337.7718 & 98.1660 & - & - & 12.46 & 0.95 & 0.90 & 4944.93 \\
\hline & & Above 7 days & -317.3191 & 95.4187 & - & - & 14.53 & 0.93 & 0.87 & 5245.88 \\
\hline \multirow{3}{*}{$\begin{array}{l}\text { Polynomial } \\
\text { (3rd order) }\end{array}$} & \multirow{3}{*}{196} & $1-3$ days & -0.001030 & 0.18343 & -8.308795 & 113.05 & 11.54 & 0.96 & 0.92 & 4796.84 \\
\hline & & 4-7 days & -0.001014 & 0.16730 & -6.569458 & 74.891 & 10.39 & 0.97 & 0.93 & 4590.75 \\
\hline & & Above 7 days & -0.000425 & 0.04119 & 1.647864 & -72.734 & 11.87 & 0.95 & 0.91 & 4851.83 \\
\hline \multirow{3}{*}{ Power } & \multirow{3}{*}{196} & $1-3$ days & 0.009635 & 2.07225 & - & - & 14.93 & 0.92 & 0.86 & 5298.01 \\
\hline & & 4-7 days & 0.041036 & 1.75641 & - & - & 15.89 & 0.92 & 0.84 & 5421.41 \\
\hline & & Above 7 days & 0.275633 & 1.33925 & - & - & 19.77 & 0.87 & 0.75 & 5849.49 \\
\hline
\end{tabular}

Following the equations of their functions, each regression model could predict a relationship of Boro yield loss with inundation depths. Figure $6 a-c$ shows the depthdamage relationships of Boro rice predicted by the five models for each set of flood duration. The calculated performance indicators are shown in Table 4.

The results depicted in Table 4 and Figure $6 a-c$ indicate that each regression model for each range of flood duration performed reasonably well with satisfactory indices. Even the simplest linear-type model showed good performance, with CC and CD values ranging from 0.89 to 0.95 and from 0.80 to 0.90 , respectively. However, the polynomial regression model performed the best for 1-3 days of flood duration. It showed a higher magnitude of CC (0.96) and CD (0.92) values together with the lower indices of SE (11.54) and AICC (4796.84). For 4-7 days and more than 7 days of inundation, on the other hand, the logistic model overtopped the other models and resulted with higher indices of CC and CD (ranging between 0.96 and 0.97 and between 0.92 and 0.93 , respectively) together 
with a lower range of SE (from 10.62 to 11.52) and AICC (from 4631.30 to 4791.76) indices. Therefore, by considering their best performance among the selected models, the thirdorder polynomial type for 1-3 days and the logistic type for 4-7 days and more than 7 days of inundation were chosen to develop the damage function of Boro rice for this study.
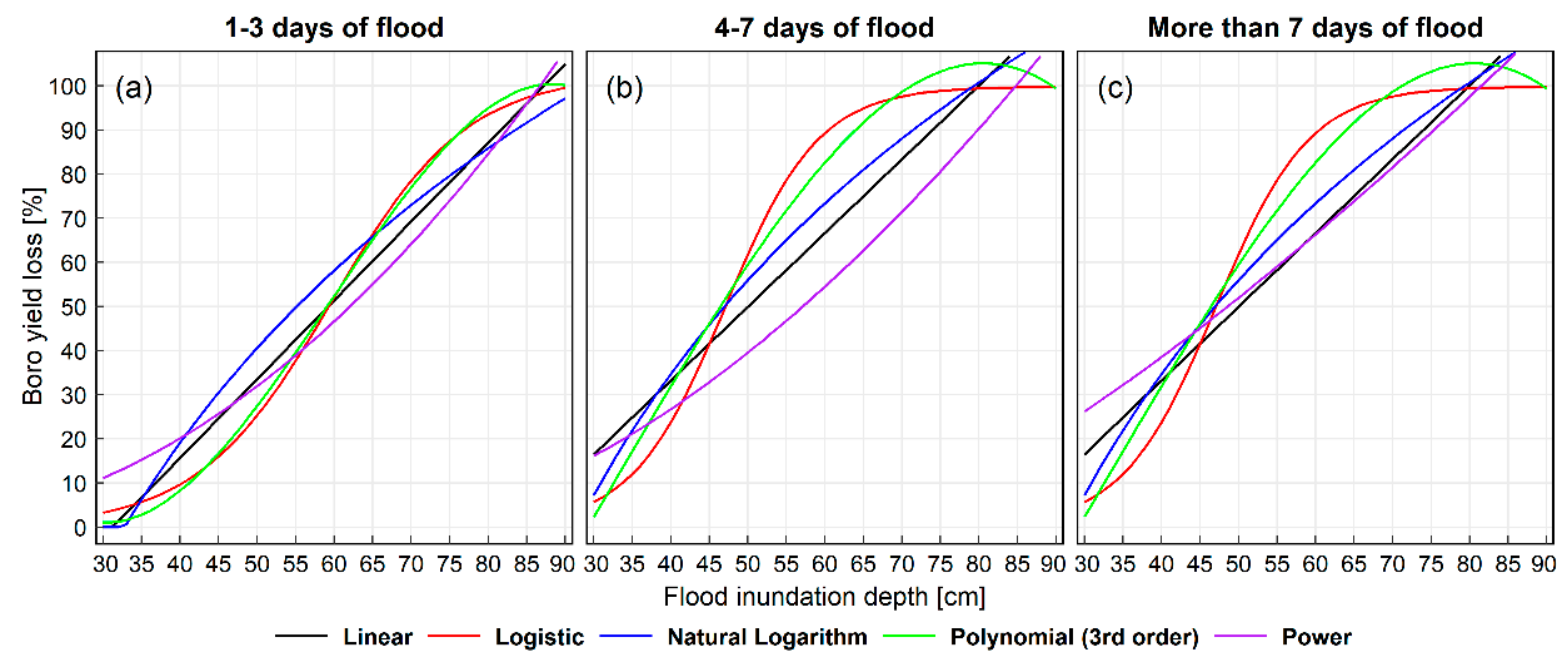

Figure 6. Damage curves fitted by five regression models for the flood durations of (a) 1-3 days, (b) 4-7 days, and (c) more than 7 days.

To further verify the best selected three regression models, a validation approach was conducted in this study by dividing the survey data of rice damage (196 samples) into two groups. First, 100 samples were used as training data to set up the three models and the next 96 samples were used as testing data to check the models. First, regression analysis with the 100 samples was performed with the best three models and the damage functions were derived for the flood durations of 1-3 days, 4-7 days, and more than 7 days. Then, an average yield loss from the 96 sample was calculated according to the flood depths of $30,45,60,75$, and $90 \mathrm{~cm}$ and for the three sets of flood durations. Finally, a comparison between the yield loss estimated from the 96 samples and the yield loss calculated from the damage functions derived from the 100 samples is shown in Figure 7a-c.

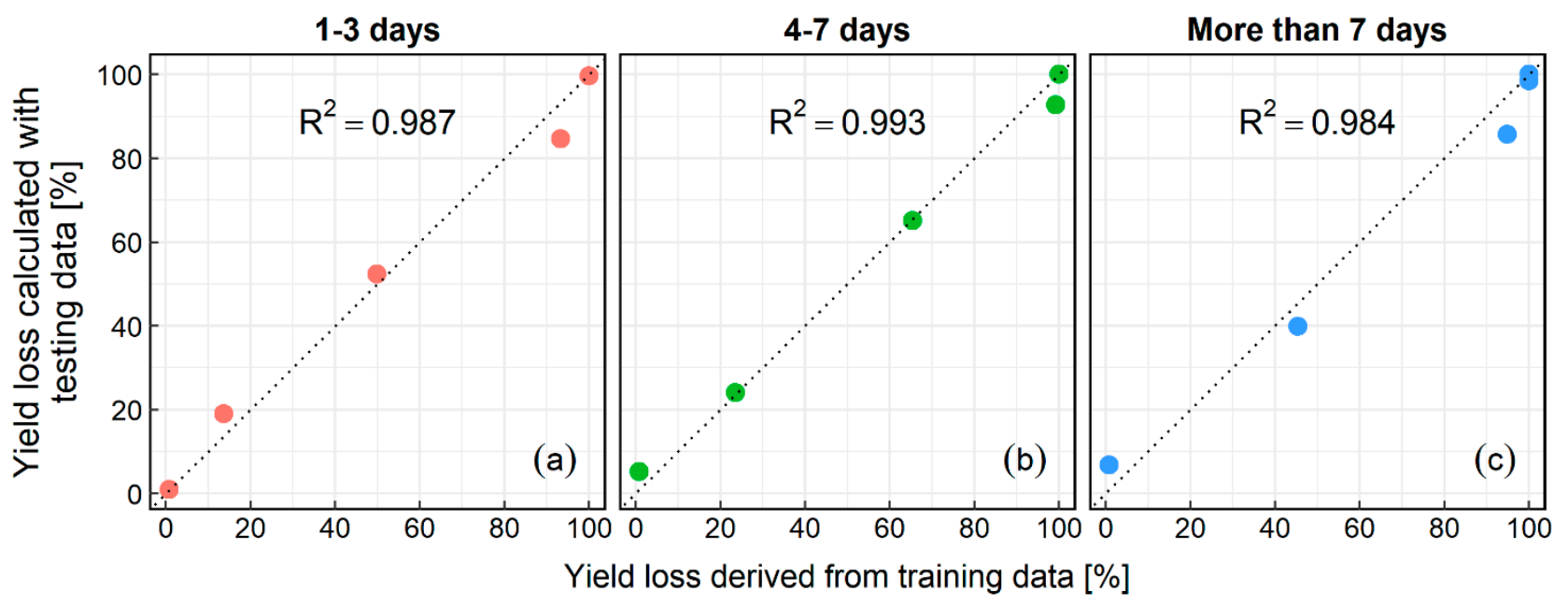

Figure 7. Comparison between yield losses of the training and testing data of the rice damage samples for the flood durations of (a) 1-3 days, (b) 4-7 days, and (c) more than 7 days.

The results shown in Figure $7 \mathrm{a}-\mathrm{c}$ indicate that the best performing models selected for developing Boro rice damage curves produced the satisfactory results with a CD (R- 
squared) values ranging from 0.98 to 0.99 . Therefore, it is evident that the best selected regression models are likely to develop flood damage functions of Boro rice in the study area. Figure $8 \mathrm{a}-\mathrm{c}$ shows the developed damage curves of Boro rice for three sets of flood duration. To incorporate the uncertainty of the collected data, an uncertainty band of one standard deviation $( \pm 1 \sigma)$ was integrated with the damage curves. As pointed out earlier, this study considered only the maturity stage of Boro rice for damage estimation. The damage curves developed at this stage of the rice showed the difference in the shape, thresholds for damage occurrence, and range of expected damage ratios with the other existing damage curves developed by various studies [31,37-39]. This might be due to the fact of containing regional differences in various contexts such as crop type, flood timing and duration, potential yield, cultivation practices, etc. The developed curves revealed that the rice yield became nearly zero when the flood height exceeded $75 \mathrm{~cm}$ (the depth at which rice grains start to flourish), regardless of the inundation duration. One finding revealed from the developed curves was that there was no damage to Boro paddies when the water level remained up to an average depth of $25 \mathrm{~cm}$ (at which the tiller of rice evolves). This finding can effectively be used to facilitate excess water during the flood period to reduce agricultural risk, as a huge volume of floodwater can be diverted into around 423 Haors (in which Boro rice is cultivated) up to a $25 \mathrm{~cm}$ depth. However, flood inundation up to such a depth in a Boro field usually delays the maturity of rice by about 15-20 days.
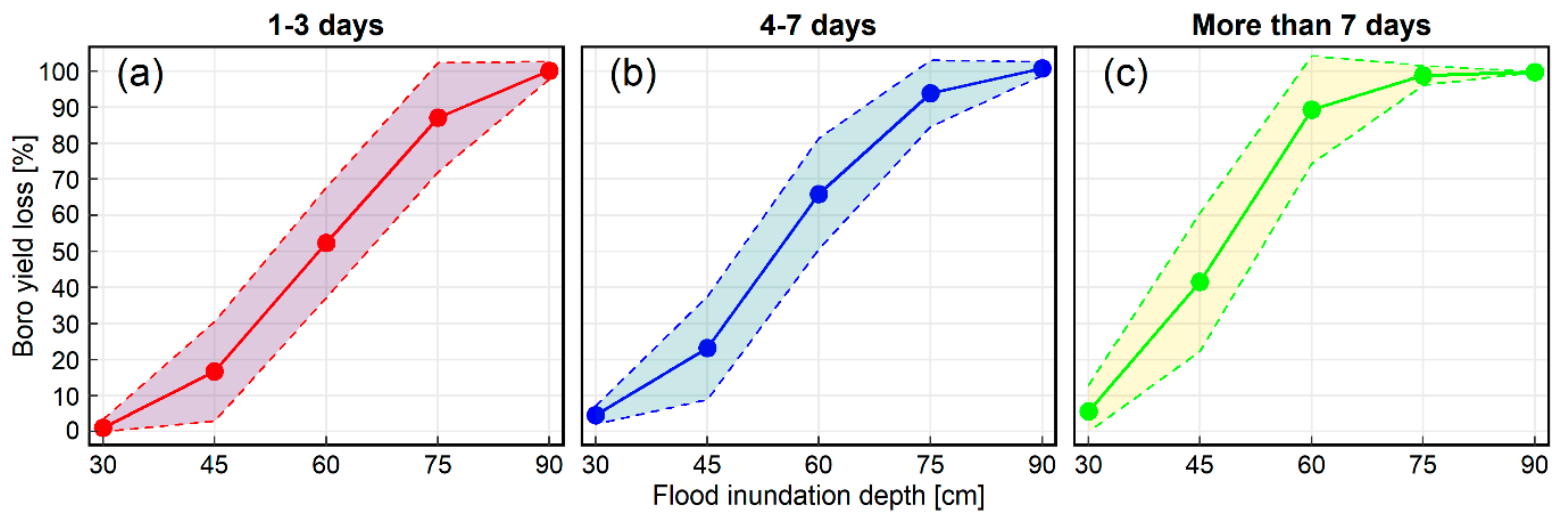

Figure 8. Flood damage curves of Boro rice developed by this study for the duration ranges of (a) 1-3 days, (b) 4-7 days, and (c) more than 7 days. One standard deviation $( \pm 1 \sigma)$ was added to show the uncertainty bands.

\subsection{Development of Household Damage Curves}

Household damage curves were developed for house and household property damage. Of 165 flood-affected households surveyed in this study, 91 were categorized as Mud, 41 as Brick, and 33 as Concrete. The characteristics of these households observed during the survey are shown in Table 5.

Table 5. Characteristics of different house types observed in the study area.

\begin{tabular}{|c|c|c|c|c|c|}
\hline \multirow{2}{*}{ House Type } & \multicolumn{2}{|c|}{ Proportion } & \multirow{2}{*}{$\begin{array}{l}\text { Avg. Plinth Level } \\
\text { (m) }\end{array}$} & \multirow{2}{*}{$\begin{array}{c}\text { Avg. Building } \\
\text { Value } \\
\left(10^{3} \text { BDT/USD) }\right.\end{array}$} & \multirow{2}{*}{$\begin{array}{c}\text { Avg. Property } \\
\text { Value } \\
\left(10^{3} \mathrm{BDT} / \mathrm{USD}\right)\end{array}$} \\
\hline & Size & $\%$ & & & \\
\hline Mud & 91 & 55 & 1.5 & $276 / 3247$ & $110 / 1294$ \\
\hline Brick & 41 & 25 & 1.8 & $685 / 8059$ & $191 / 2247$ \\
\hline Concrete & 33 & 20 & 1.8 & $1436 / 16,894$ & $319 / 3753$ \\
\hline
\end{tabular}

$\mathrm{BDT}=$ Bangladesh currency $=$ Bangladesh Taka; 1 USD = 85 BDT.

\subsubsection{House Building Damage Curves}

House building damage is mainly dominated by flood heights above the plinth level (PL). Considering varying flood heights above PL of 30, 60, 90, 120, 150, 180, and $215 \mathrm{~cm}$, 
damage data to house buildings were collected in a monetary value expressed in thousand BDT. To be used for different times and space, they were normalized and expressed in percent damage using Equation (2). The variability of the building damage data between the sub-districts was also investigated and is presented in Figure $9 a-c$.
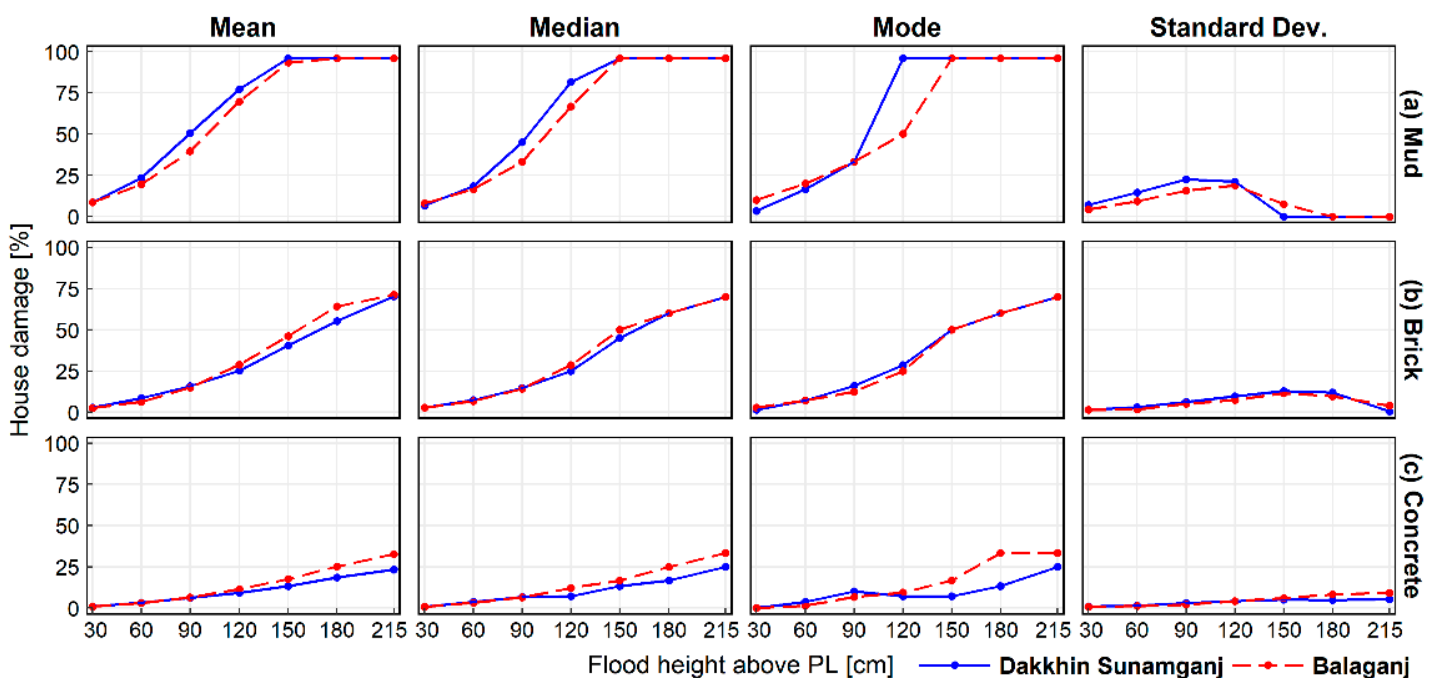

Figure 9. Statistical comparison between the house damage datasets of two sub-districts for (a) Mud, (b) Brick, and (c) Concrete buildings.

Because of the similar topography, land use, households, and people's livelihoods in the study area, an insignificant variation of the house damage data was observed between the sub-districts (Figure $9 \mathrm{a}-\mathrm{c}$ ). Therefore, by considering the datasets of two sub-districts as one, the depth-damage relationships were depicted for all three types of houses in box and whisker plots and are presented in Figure 10a-c. The mean, median, mode, and standard deviation of the dataset are also shown in the figure.
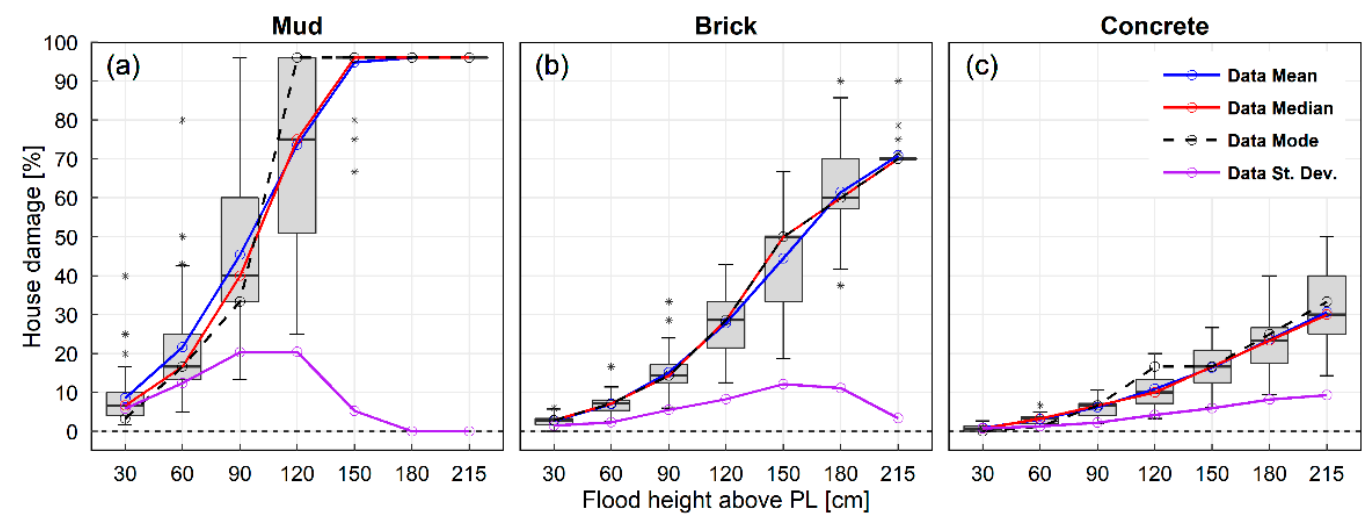

Figure 10. Relationships between house damage and flood heights drawn with 165 samples for different house types of (a) Mud, (b) Brick, and (c) Concrete. Asterisks are the outliers of the data. Outliers are located outside the whiskers of the plot.

A Larger variation was observed in Mud house damage, particularly for 90 and 120 $\mathrm{cm}$ of flood heights. This might be due to the effect of household responses that were dependent on the experience, knowledge, fatigue, and memories of the respondents [52]. Another reason could be the variety of building materials used for constructing Mud houses. The roofs of some Mud houses are made of iron sheets, whereas some are of straws. The walls are sometimes built with straws and sometimes with jute sticks or bamboo sticks. The Brick and Concrete houses showed a mild variability within the damage data, which 
indicated the consistency of the collected data regardless of the regions. Although the house damage data resulted in larger to mild variability for all three types of houses, the standard deviations $(\sigma)$ of the data were found satisfactorily low (an average of 7\%) for each type of house (Figure 10a-c, purple-colored line), which indicates that the collected date were reliable. Hence, with these data, regression analyses with five models were performed to identify the best depth-damage relationships for the three types of houses, and the results are presented in Table 6 and Figure 11a-c.

Table 6. Results of five regression models performed with 165 samples of house building damage data.

\begin{tabular}{|c|c|c|c|c|c|c|c|c|c|c|}
\hline \multirow{2}{*}{$\begin{array}{c}\text { Regression } \\
\text { Models }\end{array}$} & \multirow{2}{*}{$\begin{array}{c}\text { No. of } \\
\text { Samples }\end{array}$} & \multirow{2}{*}{$\begin{array}{l}\text { House } \\
\text { Type }\end{array}$} & \multicolumn{4}{|c|}{ Value of Parameters } & \multirow{2}{*}{ SE } & \multirow{2}{*}{$\mathrm{CC}$} & \multirow{2}{*}{ CD } & \multirow{2}{*}{ AICC } \\
\hline & & & $\mathbf{a}$ & b & c & d & & & & \\
\hline \multirow{4}{*}{ Linear } & 91 & Mud & -2.308075 & 0.5351 & - & - & 16.27 & 0.89 & 0.80 & 3553.63 \\
\hline & 41 & Brick & -15.62295 & 0.4010 & - & - & 8.55 & 0.94 & 0.89 & 1231.80 \\
\hline & 33 & Concrete & -6.782667 & 0.1649 & - & - & 5.85 & 0.87 & 0.75 & 815.95 \\
\hline & 91 & Mud & 99.00861 & 44.638 & 0.041039 & - & 12.46 & 0.94 & 0.88 & 3215.06 \\
\hline \multirow{2}{*}{ Logistic } & 41 & Brick & 79.30398 & 62.377 & 0.029431 & - & 7.54 & 0.96 & 0.92 & 1160.66 \\
\hline & 33 & Concrete & 39.41865 & 47.180 & 0.023697 & - & 5.60 & 0.88 & 0.77 & 797.24 \\
\hline \multirow{3}{*}{$\begin{array}{c}\text { Natural } \\
\text { Logarithm }\end{array}$} & 91 & Mud & -177.9507 & 51.972 & - & - & 15.30 & 0.91 & 0.82 & 3474.91 \\
\hline & 41 & Brick & -131.2998 & 35.499 & - & - & 12.70 & 0.87 & 0.76 & 1458.76 \\
\hline & 33 & Concrete & -53.69458 & 14.456 & - & - & 7.13 & 0.79 & 0.63 & 907.54 \\
\hline \multirow{3}{*}{$\begin{array}{l}\text { Polynomial } \\
\text { (3rd order) }\end{array}$} & 91 & Mud & -0.000033 & 0.0097 & -0.118620 & 3.0656 & 12.53 & 0.94 & 0.88 & 3222.89 \\
\hline & 41 & Brick & -0.000018 & 0.0073 & -0.476719 & 11.582 & 7.60 & 0.96 & 0.92 & 1165.95 \\
\hline & 33 & Concrete & -0.000002 & 0.0013 & -0.043291 & 1.1611 & 5.61 & 0.88 & 0.77 & 798.68 \\
\hline \multirow{3}{*}{ Power } & 91 & Mud & 0.058441 & 1.4348 & - & - & 16.24 & 0.89 & 0.80 & 3551.03 \\
\hline & 41 & Brick & 0.011702 & 1.6321 & - & - & 8.14 & 0.95 & 0.90 & 1203.81 \\
\hline & 33 & Concrete & 0.002243 & 1.7762 & - & - & 5.59 & 0.88 & 0.77 & 795.46 \\
\hline
\end{tabular}

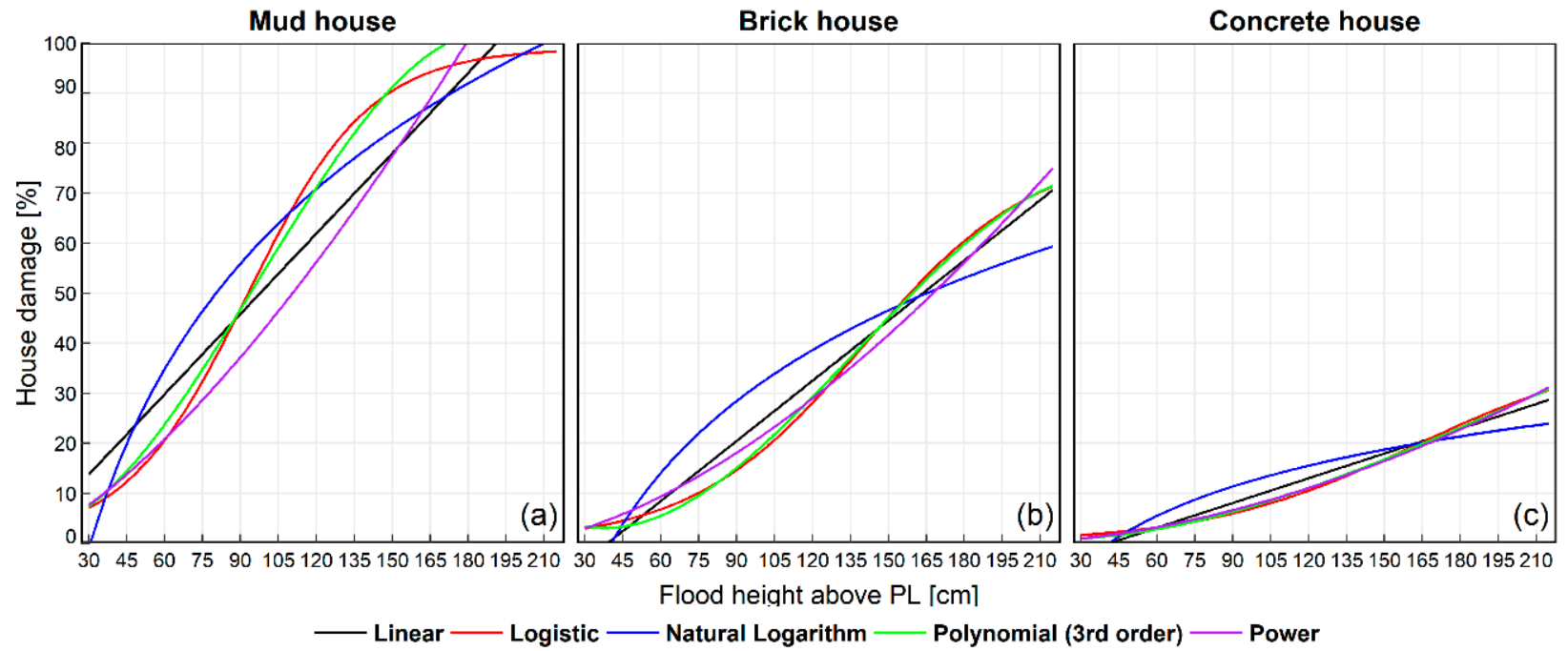

Figure 11. Depth-damage relationships fitted by five regression models for the damage to different house types of (a) Mud, (b) Brick, and (c) Concrete.

The results, shown in Table 6 and Figure 11a-c, revealed the satisfactory performance of each regression model to establish depth-damage relationships for all three types of houses. However, the logistic model performed the best for Mud and Brick houses, producing larger CC and CD values with smaller SE and AICC values (Table 6 and Figure 11a,b). For Concrete-type houses, on the other hand, the power, logistic, and polynomial models produced identical CC and CD indices; however, the other two indices (SE and AICC) showed better values for the power model than the logistic and polynomial models (Table 6 and Figure 11c). Therefore, flood damage curves for all the three types of houses were 
developed using the results of these best-performing models (i.e., the logistic model for Mud and Brick houses and the power model for Concrete houses), as shown in Figure 12a-c. To incorporate the uncertainty in the collected building damage dataset, an uncertainty band of one standard deviation $( \pm 1 \sigma)$ was integrated with the developed damage curves. The curves revealed that the flood damage to Brick and Concrete houses did not reach $100 \%$ for any selected flood heights because of their building materials and construction methods. On the other hand, the construction method and materials of Mud houses make them most vulnerable to floods, compared to the other two types of houses.
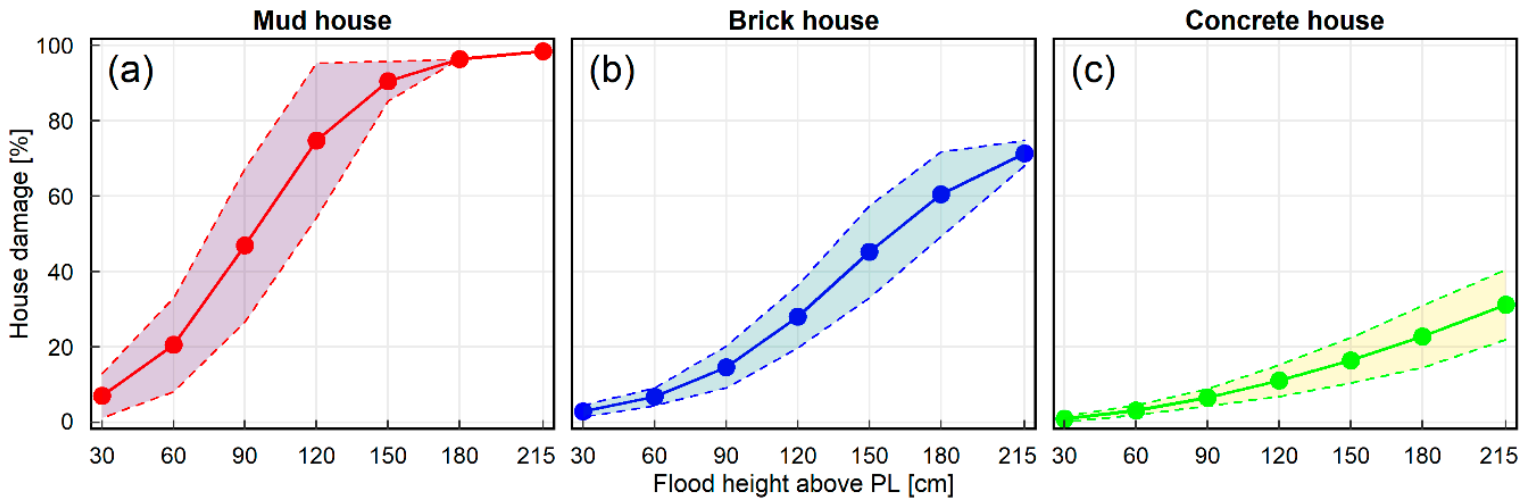

Figure 12. Developed flood damage curves for the building damage to (a) Mud, (b) Brick, and (c) Concrete types of houses. One standard deviation $( \pm 1 \sigma)$ was added to show the uncertainty bands.

\subsubsection{Household Property Damage Curves}

Flood damage data for household property were collected in thousand BDT for all 165 samples. The data were converted into percent damage using Equation (3). This percent damage data for each sub-district were statistically compared based on four indices, as shown in Figure 13a-c. No significant variability was observed; hence, to see the flood depth-damage relationship of household property, box and whisker plots were drawn for the entire dataset and are presented in Figure $14 \mathrm{a}-\mathrm{c}$ with the data's mean, median, mode, and standard deviation.
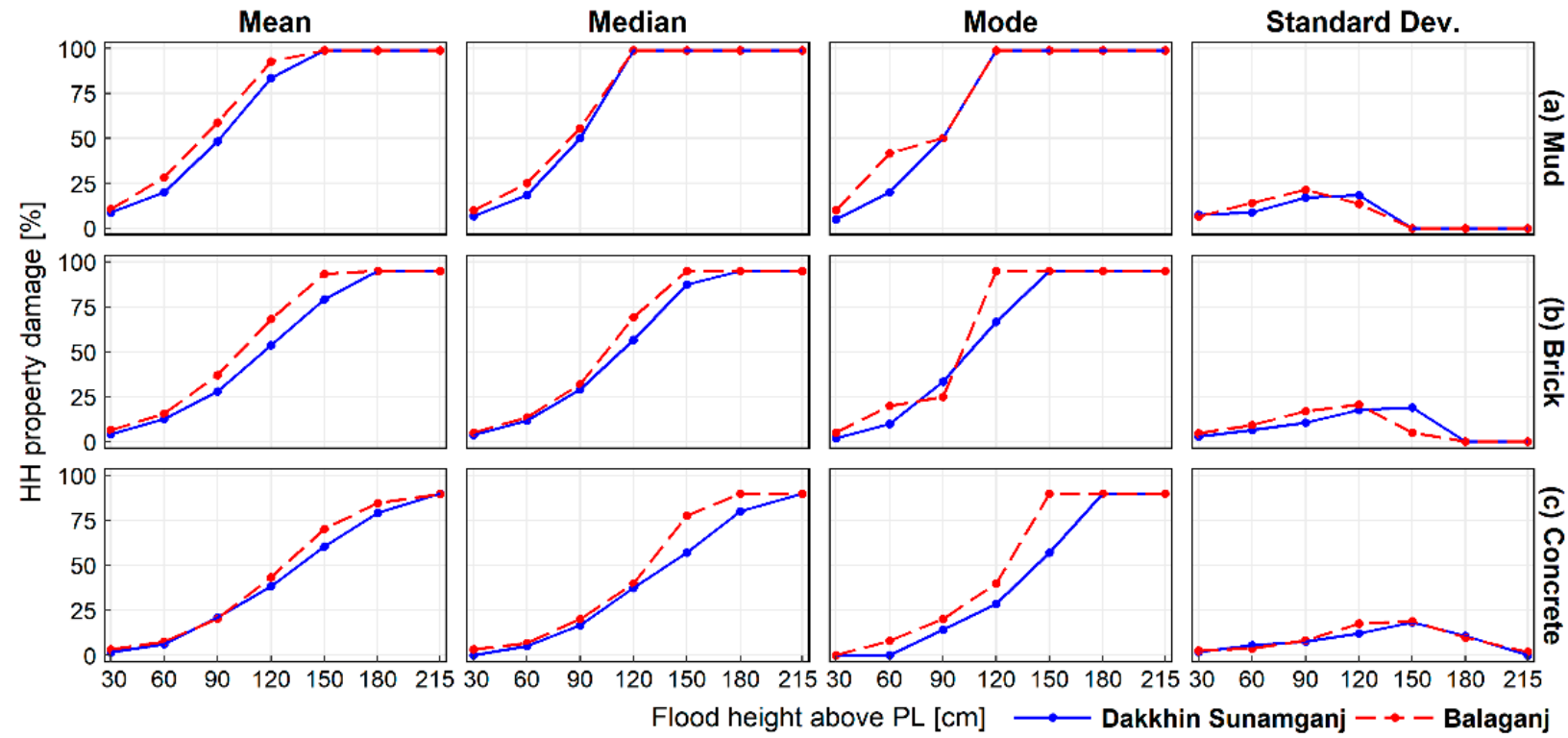

Figure 13. Comparison of the household $(\mathrm{HH})$ property damage data between the two sub-districts for different house types of (a) Mud, (b) Brick, and (c) Concrete. 

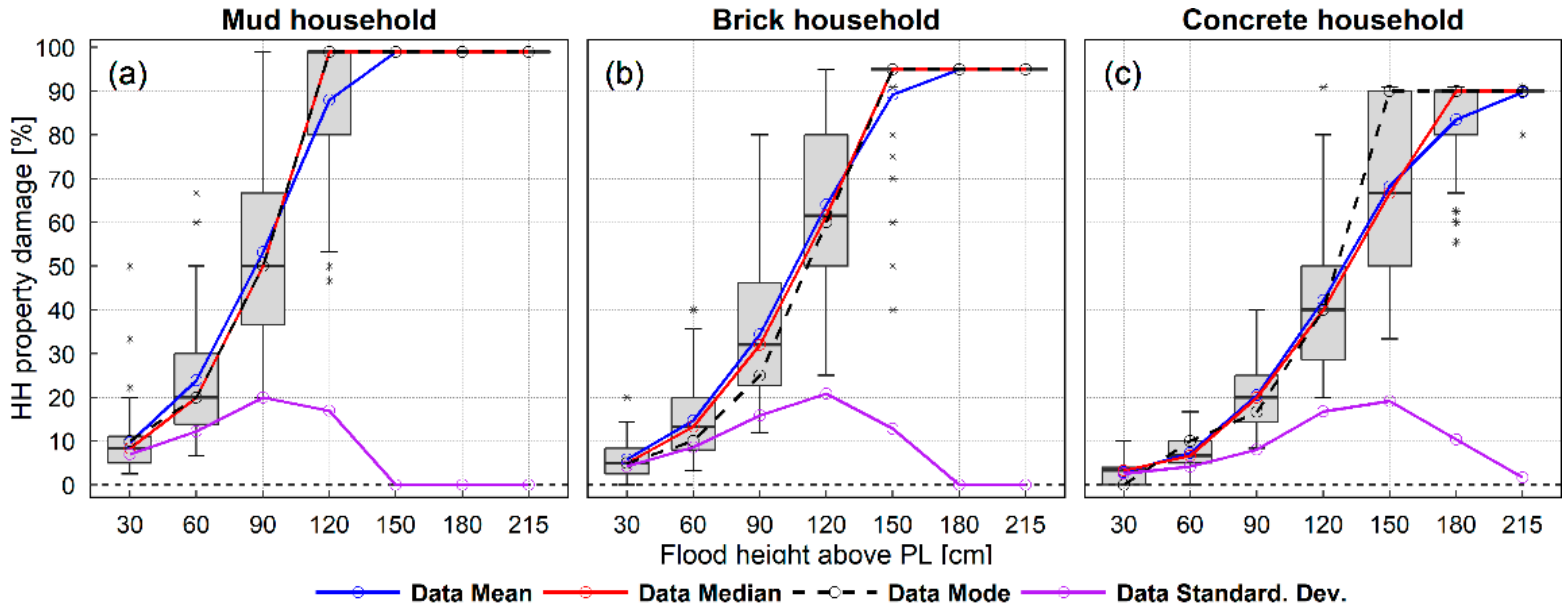

Figure 14. Distribution of the damage to household property against selected flood heights for 165 samples for different house types of (a) Mud, (b) Brick, and (c) Concrete. Asterisks are the outliers of the data. Outliers are located outside the whiskers of the plot.

The distribution of the in-house property damage dataset (Figure 14a-c) also showed inconsistency and variability, as observed in Figure 10a-c for the building damage dataset, and that may be due to the same reasons described in Section 4.2.1. However, the property damage data produced an average of only $8 \%$ standard deviations. With such a minimum value, regression analyses with the five models were also conducted using the property damage data for all three types of houses to predict flood depth and property damage relationships. The model results are presented in Table 7 , and the damage curves predicted by each model for the three types of households are shown in Figure 15a-c.

Table 7. Results of different regression models performed with the household property damage data collected for 165 samples.

\begin{tabular}{|c|c|c|c|c|c|c|c|c|c|c|}
\hline \multirow{2}{*}{$\begin{array}{l}\text { Regression } \\
\text { Models }\end{array}$} & \multirow{2}{*}{$\begin{array}{c}\text { No. of } \\
\text { Samples }\end{array}$} & \multirow{2}{*}{$\begin{array}{c}\text { Household } \\
\text { Type }\end{array}$} & \multicolumn{4}{|c|}{ Value of Parameters } & \multirow{2}{*}{ SE } & \multirow{2}{*}{$\mathrm{CC}$} & \multirow{2}{*}{ CD } & \multirow{2}{*}{ AICC } \\
\hline & & & $\mathbf{a}$ & $\mathbf{b}$ & c & d & & & & \\
\hline \multirow{4}{*}{ Linear } & 91 & Mud & 2.338476 & 0.5389 & - & - & 17.52 & 0.88 & 0.78 & 3647.89 \\
\hline & 41 & Brick & -10.90645 & 0.5616 & - & - & 15.13 & 0.92 & 0.84 & 1559.52 \\
\hline & 33 & Concrete & -19.97812 & 0.5375 & - & - & 12.73 & 0.93 & 0.87 & 1175.30 \\
\hline & 91 & Mud & 101.1704 & 60.144 & 0.048048 & - & 11.50 & 0.95 & 0.91 & 3112.44 \\
\hline \multirow[t]{2}{*}{ Logistic } & 41 & Brick & 98.02995 & 98.029 & 0.042513 & - & 11.83 & 0.95 & 0.90 & 1419.41 \\
\hline & 33 & Concrete & 92.86422 & 114.31 & 0.038246 & - & 11.09 & 0.95 & 0.90 & 1112.76 \\
\hline \multirow{3}{*}{$\begin{array}{l}\text { Natural } \\
\text { Logarithm }\end{array}$} & 91 & Mud & -180.1408 & 53.550 & - & - & 14.95 & 0.92 & 0.84 & 3445.67 \\
\hline & 41 & Brick & -188.6330 & 53.116 & - & - & 16.07 & 0.90 & 0.82 & 1594.08 \\
\hline & 33 & Concrete & -179.4930 & 48.546 & - & - & 16.80 & 0.88 & 0.77 & 1303.46 \\
\hline \multirow{3}{*}{$\begin{array}{c}\text { Polynomial } \\
\text { (3rd order) }\end{array}$} & 91 & Mud & -0.000027 & 0.0067 & 0.323612 & -8.1503 & 12.08 & 0.94 & 0.89 & 3176.80 \\
\hline & 41 & Brick & -0.000043 & 0.0143 & -0.685676 & 14.1977 & 11.88 & 0.95 & 0.90 & 1422.68 \\
\hline & 33 & Concrete & -0.000037 & 0.0139 & -0.937985 & 19.9961 & 11.14 & 0.95 & 0.90 & 1115.94 \\
\hline \multirow{3}{*}{ Power } & 91 & Mud & 0.079741 & 1.3896 & - & - & 17.05 & 0.91 & 0.82 & 3469.94 \\
\hline & 41 & Brick & 0.270495 & 1.1164 & - & - & 15.68 & 0.91 & 0.83 & 1579.81 \\
\hline & 33 & Concrete & 0.034920 & 1.4796 & - & - & 13.17 & 0.93 & 0.86 & 1190.88 \\
\hline
\end{tabular}



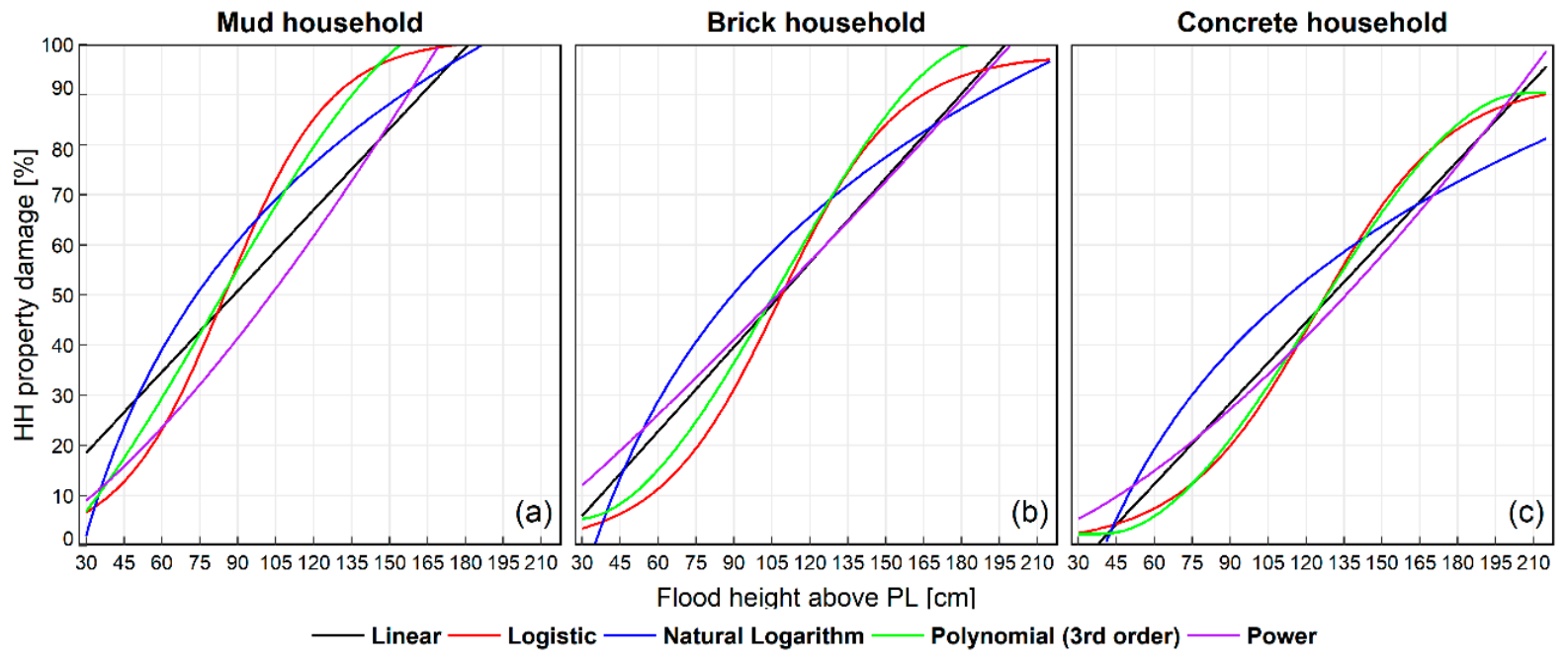

Figure 15. Depth-damage relationships fitted by five regression models for in-house property damage to different house types of (a) Mud, (b) Brick, and (c) Concrete.

Among all performance indices stated in Table 7, the logistic and polynomial models performed better than the other three models. However, the less complicated logistic model was selected as the best model over the more complicated polynomial model through the SE- and AICC-Test. Therefore, using the results of this best-performing logistic model, flood damage curves for the household property of the three house types were developed and are shown in Figure 16a-c. To incorporate the uncertainty of the collected data, an uncertainty band of one standard deviation $( \pm 1 \sigma)$ was integrated with the developed damage curves. The damage curves revealed that the owners of Mud houses are unlikely to save household goods when the flood height exceeds $150 \mathrm{~cm}$, whereas the goods of Brick and Concrete houses can be saved to some extent since they are usually constructed with an attic (loft) and/or half ceiling at lintel height. It is, thus, evident that the construction method and materials of Mud houses make the buildings and in-house property most vulnerable to floods.
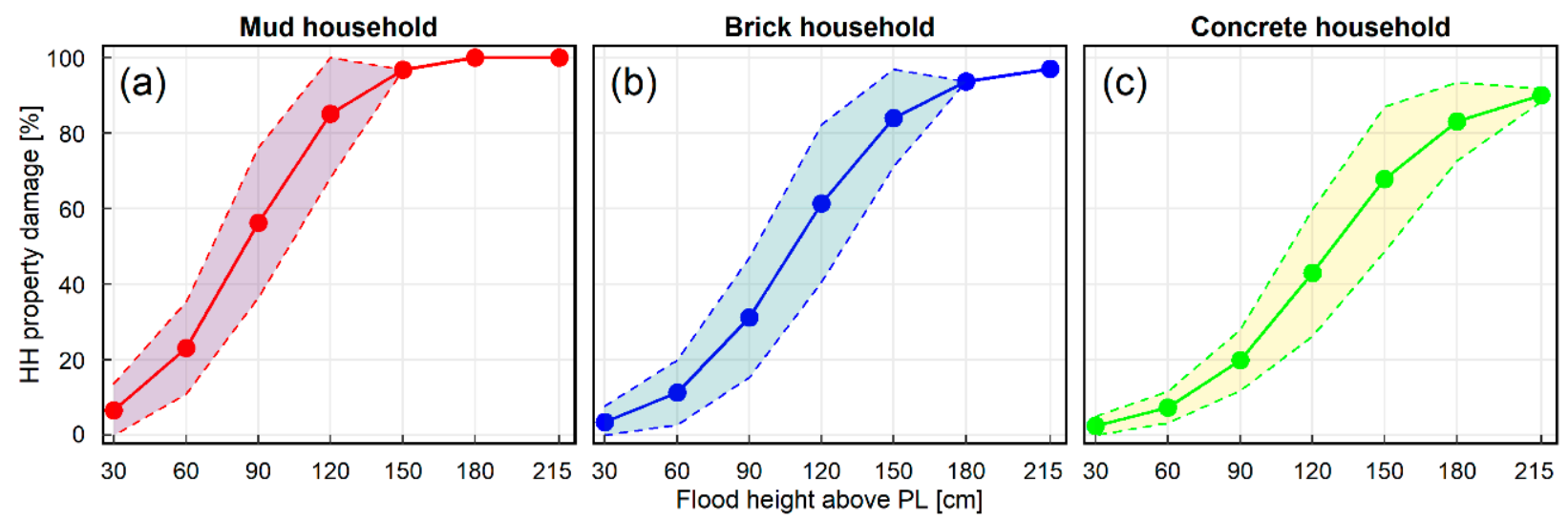

Figure 16. Developed flood damage curves of household property for (a) Mud, (b) Brick, and (c) Concrete houses. One standard deviation $( \pm 1 \sigma)$ was added to show the uncertainty bands.

\section{Validation of the Damage Curves}

This study verified the developed damage curves of Boro rice by conducting a damage assessment of the 2017 flood. In doing this, a hazard assessment and an exposure assessment were also performed. Hazard parameters such as inundation depths and duration were simulated by a 2D hydrological Rainfall-Runoff-Inundation (RRI) model $[57,58]$ forced with distributed rainfall data previously developed by the authors [28]. Figure 17a shows a 
flood inundation map generated at a $500 \mathrm{~m}$ grid resolution for the 2017 flood of the study area with a duration range of 28 days (from 1 April to 28 April). The map indicated that the study area mostly experienced a range of flood inundation depth (FID) between $0.5 \mathrm{~m}$ and $4 \mathrm{~m}$ during the 2017 flood. Figure $17 \mathrm{~b}$ shows an exposure map of Boro rice fields at a $500 \mathrm{~m}$ grid resolution by administrative districts of the study area. The raster data of the exposure map was prepared by using a previous study [59] that mapped rice area of the South Asia using MODIS Multitemporal data.
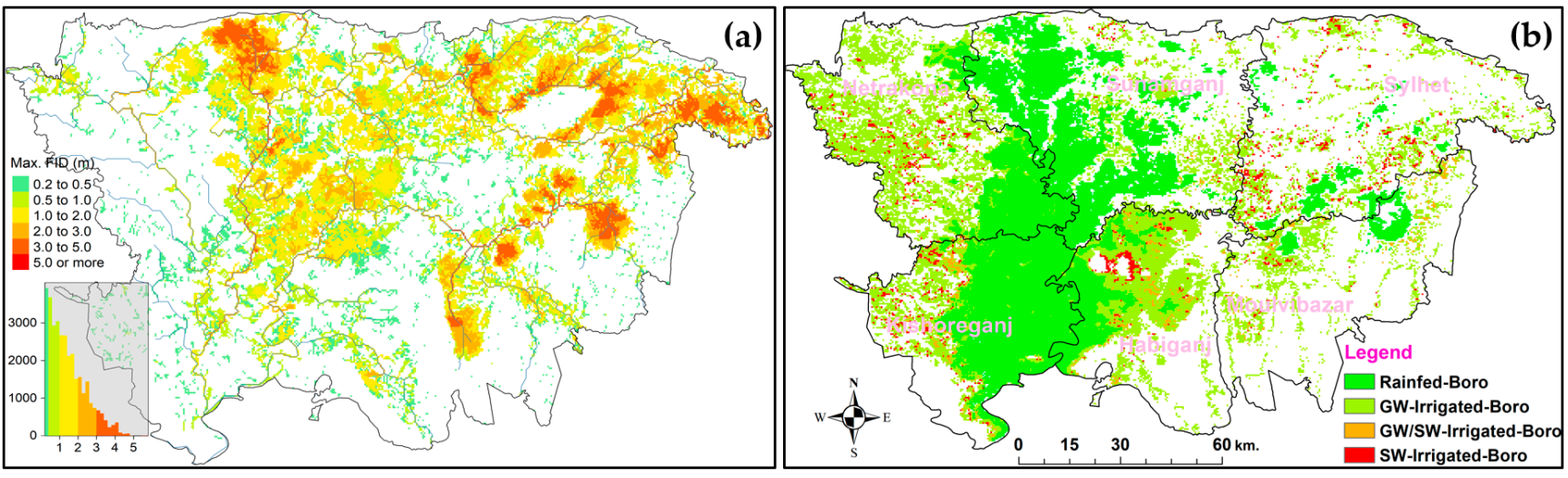

Figure 17. (a) Flood map at a $500 \mathrm{~m}$ grid generated by the RRI model for the 2017 flood in terms of maximum inundation depths, and (b) Gridded Boro extent map at $500 \mathrm{~m}$ resolution for the study area.

By combining the flood inundation map simulated by the RRI model (Figure 17a), the depth-duration-damage relationship obtained from the developed Boro damage curves (Figure $8 \mathrm{a}-\mathrm{c}$ ) and the Boro extent map (Figure 17b), a distributed flood damage map at a $500 \mathrm{~m}$ resolution for Boro rice was produced for the study area. As depicted in Table 3, the flood depth at which the damage to rice starts is $30 \mathrm{~cm}$. Therefore, the marginal flooding areas considered in this study are the areas that experience less than $30 \mathrm{~cm}$ of flood inundation. These types of marginal flooding areas in a hazard map were filtered and left out for flood damage assessment by many other studies [60-62]. Therefore, by leaving out the grid cells experiencing a marginal flooding of less than a $30 \mathrm{~cm}$ FID of the simulated hazard map, the maximum, minimum, and an average total of rice damage were estimated and compared with those of the reported damage obtained from three different sources. Table 8 shows the comparison. The damage to Boro rice estimated by this study for each case (maximum, minimum, and average total) was found to satisfactorily agree with the reported damage. The developed damage curves of house and household property were unlikely to be validated due to the lack of reported damage data.

Table 8. Comparison between estimated and reported damage of Boro rice during the 2017 flood.

\begin{tabular}{ccc}
\hline Total Boro Damage & $\begin{array}{c}\text { Estimated } \\
\text { (Million USD) }\end{array}$ & $\begin{array}{c}\text { Reported } \\
\text { (Million USD) }\end{array}$ \\
\hline Maximum & 589 & $612[63]$ \\
Minimum & 372 & $356[48]$ \\
Average & 468 & $450[64]$ \\
\hline
\end{tabular}

\section{Conclusions}

The northeastern part of Bangladesh, which is located downstream of the Meghna River basin, is frequently affected by flood disasters. To reduce such disasters and build back better, flood risk assessment is an important tool for the policy makers to identify effective counter-measures and formulate future adaptation plans. Of the three main components of a flood risk assessment model, development of flood damage functions for the estimation of flood vulnerability was the main focus of this study. Of the two types 
of flood damage functions, the empirical type has yet to be developed in Bangladesh due to the lack of an integrated and consistent damage data bank. Therefore, development of the other type, the synthetic type of damage functions, which are based on based on questionnaire survey data, was the only alternative. However, to the authors' best knowledge, the synthetic type of flood damage functions has not been established yet in Bangladesh. Therefore, as a first attempt, this paper developed a synthetic type of reliable flood damage functions for agriculture and rural households using the data collected from a well-structured questionnaire survey conducted in northeastern Bangladesh. The survey data included a total of 196 and 165 samples, respectively, for agriculture and household damage due to a flood. Agriculture damage considered the damage to Boro rice (the main crop of the study area), and household damage included the damage to buildings and household property for three types of houses (Mud, Brick, and Concrete). Variability and inconsistency were observed to some extent in the collected data for each damage class (i.e., Boro rice, house building, and in-house property). However, the standard deviations $(\sigma)$ of each class were obtained as reasonably small in quantity (an average of $7-9 \%$ ), indicating satisfactory reliability of the collected data. With the data, five regression models were performed to establish reliable depth-damage relationships. The best model based on several performance indicators was used to draw damage curves of the three damage classes.

The Boro damage curves revealed that the damage was mainly governed by flood depths and duration. The yield of Boro rice became near zero at a flood depth of about $70-75 \mathrm{~cm}$ ( rice grain height) and a flood duration of 7 days or longer. The Boro damage curves also revealed that the Boro paddies can tolerate water without any damage up to $\sim 25 \mathrm{~cm}$ depth ( rice tiller height) at their flowering through maturity stage. However, at this water depth, the maturity of the rice might be delayed by about 15-20 days. This finding can effectively be used to facilitate a huge volume of excess water during a flood time through diversion into Boro fields inside $\sim 423$ Haors up to $25 \mathrm{~cm}$ depth.

The house and in-house property damage functions revealed that the household damage is mainly dependent on inundation height above the floor level and the type of houses. Due to their construction method and building materials, Mud houses were found to be the most vulnerable to floods, and the damage became $100 \%$ when the flood height exceeded $150 \mathrm{~cm}$. The damage to Brick and Concrete houses, on the other hand, never reached 100\%. Therefore, by constructing Mud houses (construction cost: 3250 USD) in an elevated place or upgrading them to Brick houses (construction cost: $~ 8060$ USD) or Concrete houses (construction cost: $\sim 16,895$ USD), the flood risk to Mud houses can be reduced significantly.

The FDFs of Boro rice were validated to damage assessment caused by the 2017 flood. The total maximum, minimum, and average damage to Boro rice was found to be satisfactorily agreeable to those calculated by the developed FDFs. The FDFs of households were unlikely to be validated due to the lack of observed damage data.

This study has two limitations, which are likely to be addressed in future studies. First is the building size of the houses that was not considered in the questionnaire survey conducted by this study. Secondly, the changes in production costs of Boro rice due to flood were not assessed, as done by several other studies [65-67]. Since the changes in production costs due to flood are dependent on the growth stages of the rice and since the maturity stage of the rice was only considered in this study, it is, therefore, likely that the changes in production costs of rice may not play an important role in flood risk assessment. However, this can be explored and addressed in the future studies.

Despite having few limitations, the flood damage functions/curves (FDFs) developed in this study revealed several findings that can help to reduce flood risk in the study area. In addition, the FDFs can be useful for pre- and post-disaster flood damage assessments and potential flood risk assessment under global change for road-mapping sustainable and effective management of flood disasters. In a future study, the FDFs will be further 
investigated for the applicability to potential flood risk assessment under global change in the study area.

Author Contributions: Conceptualization, I.M.K., and M.R.; methodology, I.M.K., M.R. and K.T.; software, I.M.K.; writing—original draft preparation, I.M.K.; writing—review and editing, I.M.K., M.R., K.T. and M.O. All authors have read and agreed to the published version of the manuscript.

Funding: This research was supported by the Public Works Research Institute (PWRI), Japan and Japan Science and Technology Agency (JST).

Institutional Review Board Statement: Not applicable.

Informed Consent Statement: Not applicable.

Data Availability Statement: Upon request, raw data that support the findings of this study are available from the corresponding author.

Acknowledgments: The authors would like to thank the International Centre for Water Hazard and Risk Management (ICHARM) and Public Works Research Institute (PWRI), Japan, for supporting this research. Thanks are also given to the respected interviewees who effectively responded while the questionnaire survey was conducted. Additionally, thanks are given to the Bangladesh Water Development Board for providing the necessary support and security during the survey period.

Conflicts of Interest: The authors declare no conflict of interest.

\section{Appendix A}

Sample questionnaire for Boro rice production damage due to floods.

[Please consider maturity stage (20-30 days before harvesting) of Boro paddy (BR28/BR-29), only pre-monsoon flash flood (April flood) was considered]

Name of interviewee:

District:
Occupation:
Sub-district:
Union:

(a) Please provide general information of Boro paddy at maturity stage

1. $\quad$ Type of Farm holding: $\square$ Small (5-249 decimal of operating land) $\square$ Medium (250-749 decimal of operating land) $\square$ Large (>749 decimal of operating land)

2. Full Length/height of Boro paddy $=$ $\mathrm{ft}$. inch

3. Average expected yield $=$ Maund/Bigha

4. How many days your Boro paddy was inundated for?

\begin{tabular}{|c|c|c|c|c|c|}
\hline Floods & 2004 & 2010 & 2016 & 2017 & Comments \\
\hline Days & & & & & \\
\hline
\end{tabular}

5. What was the maximum inundation depth your Boro paddy experienced?

\begin{tabular}{|c|c|c|c|c|c|}
\hline Floods & 2004 & 2010 & 2016 & 2017 & Comments \\
\hline Depth (ft.) & & & & & \\
\hline
\end{tabular}

6. How much was the actual Boro rice production (Maund/Bigha)?

\begin{tabular}{|c|c|c|c|c|c|}
\hline Floods & 2004 & 2010 & 2016 & 2017 & Comments \\
\hline Production & & & & & \\
\hline
\end{tabular}

(b) Please provide information of reduced Boro production due to inundation depth and duration

\begin{tabular}{|c|c|c|c|c|}
\hline \multirow{2}{*}{$\begin{array}{c}\text { Inundation } \\
\text { depth (ft.) }\end{array} 0.75$} & \multicolumn{2}{|c|}{ Reduced Production (Maund/Bigha) } & \multirow{2}{*}{ Comments } \\
\cline { 2 - 4 } & 1-3 Days & 4-7 Days & Above 7 Days & \multirow{2}{*}{} \\
\hline 1 & Average expected yield = Maund/Bigha & \\
\hline 1.5 & & & & \\
\hline 2 & & & & \\
\hline 2.5 & & & & \\
\hline$>3$ & & & & \\
\hline
\end{tabular}

Unit conversion: 1 Maund = 37.3242 kg.;1 Bigha $=33$ decimal; 1 ft. $=12$ inch;1 inch $=$ $2.54 \mathrm{~cm}$. 


\section{Appendix B}

Sample questionnaire for house and household assets' damage due to floods.

(Both Pre-monsoon and monsoon floods were considered)

Name of interviewee: Occupation: Sub-district:

District:

(a) Please provide general information on house and household assets:

1. Type of house (with photograph): $\square$ Packa (made of brick, cement, sand; concrete/CI sheet roof) $\square$ Semi-Packa (made of brick column and CI sheet; CI sheet roof) $\square$ Kaccha (made of mud and clay; Straw/CI sheet roof)

2. Floor level from ground $=$ $\mathrm{ft}$. inch

3. Approximate value of house $=$ Thousand taka

4. Approximate value of household assets = Thousand taka

5. How many days your house was inundated for?

\begin{tabular}{|c|c|c|c|c|c|c|}
\hline $\begin{array}{c}\text { Floods } \\
\text { Days }\end{array}$ & 2004 & 2010 & 2016 & 2017 & 2018 & Comments \\
\cline { 2 - 7 } & & & & & & \\
\hline
\end{tabular}

6. How maximum the inundation depth above floor level your house was experienced?

\begin{tabular}{|c|c|c|c|c|c|c|}
\hline Floods & 2004 & 2010 & 2016 & 2017 & 2018 & Comments \\
\cline { 2 - 7 } Depth (ft.) & & & & & & \\
\hline
\end{tabular}

7. How much was the house recovery cost after flood (Thousand taka)?

\begin{tabular}{|c|c|c|c|c|c|c|}
\hline $\begin{array}{c}\text { Floods } \\
\text { Cost }\end{array}$ & 2004 & 2010 & 2016 & 2017 & 2018 & Comments \\
\cline { 2 - 6 } & & & & & & \\
\hline
\end{tabular}

8. How much was the loss of household assets in the flood (Thousand taka)?

\begin{tabular}{|c|c|c|c|c|c|c|}
\hline $\begin{array}{c}\text { Floods } \\
\text { Loss }\end{array}$ & 2004 & 2010 & 2016 & 2017 & 2018 & Comments \\
\cline { 2 - 7 } & & & & & & \\
\hline
\end{tabular}

(b) Please provide information on recovery cost of house according to inundation depth

\begin{tabular}{|c|c|c|}
\hline \multirow{2}{*}{$\begin{array}{c}\text { Inundation depth (ft.) } \\
<^{*} \mathrm{FL}\end{array}$} & $\begin{array}{c}\text { Recovery cost (Thousand taka) } \\
\text { after floods }\end{array}$ & Comments \\
\cline { 2 - 3 } & $\begin{array}{c}\text { No damage } \rightarrow \text { Value of house } \\
\text { = Thousand taka }\end{array}$ & \\
\hline 1 & & \\
\hline 2 & & \\
\hline 3 & & \\
\hline 4 & & \\
\hline 6 & & \\
\hline 7 & & \\
\hline 8 and above & & \\
\hline
\end{tabular}

(c) Please provide information on loss of household assets according to inundation depth

\begin{tabular}{|c|c|c|}
\hline \multirow{2}{*}{$\begin{array}{c}\text { Inundation depth (ft.) } \\
<^{*} \mathrm{FL}\end{array}$} & $\begin{array}{c}\text { Recovery cost (Thousand taka) } \\
\text { after floods }\end{array}$ & Comments \\
\cline { 2 - 3 } & $\begin{array}{c}\text { No damage } \rightarrow \text { Value of assets } \\
\text { = Thousand taka }\end{array}$ & \\
\hline 1 & & \\
\hline 2 & & \\
\hline 3 & & \\
\hline 4 & & \\
\hline 5 & & \\
\hline 6 & & \\
\hline 7 and above & & \\
\hline
\end{tabular}

${ }^{*} \mathrm{FL}=$ Floor level from ground; Unit conversion: $1 \mathrm{ft} .=12 \mathrm{inch} ; 1$ inch $=2.54 \mathrm{~cm}$. 


\section{References}

1. Nishat, B.; Rahman, S.M.M. Water Resources Modeling of the Ganges-Brahmaputra-Meghna River Basins Using Satellite Remote Sensing Data1. JAWRA J. Am. Water Resour. Assoc. 2009, 45, 1313-1327. [CrossRef]

2. FAO_Food and Agriculture Organization of the United Nations. Irrigation in Southern and Eastern Asia in Figures, AQUASTAT Survey-2011; FAO Water Report \#37; FAO: Rome, Italy, 2012.

3. Chowdhury, M.R. An Assessment of Flood Forecasting in Bangladesh: The Experience of the 1998 Flood. Nat. Hazards 2000, 22, 139-163. [CrossRef]

4. Mirza, M.M.Q. Three Recent Extreme Floods in Bangladesh: A Hydro-Meteorological Analysis. Nat. Hazards 2003, $28,35-64$. [CrossRef]

5. Quddus, M.A. Crop Production Growth in Different Agro-Ecological Zones of Bangladesh. J. Bangladesh Agric. Univ. 2009, 7, 351-360. [CrossRef]

6. Alam, M.S.; Quayum, M.; Islam, M. Crop Production in the Haor Areas of Bangladesh: Insights from Farm Level Survey. Agriculturists 2011, 8, 88-97. [CrossRef]

7. Rabby, T.; Alam, G.M.; Mishra, P.; Hoque, K.; Nair, S. Different Economic and Policy Perspectives in Micro Population for Sustainable Development: A Study of the Haor Livelihood in Bangladesh. Afr. J. Bus. Manag. 2011, 5, $2475-2492$.

8. Kamruzzaman, M.; Shaw, R. Flood and Sustainable Agriculture in the Haor Basin of Bangladesh: A Review Paper. Univers. J. Agric. Res. 2018, 6, 10-49. [CrossRef]

9. Parry, B.L. Think the Weather Bad's Here? Spare a Thought for These Indian Villagers Who Live in the Wettest Place in the World with 40 FEET of Rain a Year. Available online: http:/ / www.dailymail.co.uk/news/article-2471421/Indias-Mawsynram-villagerslive-wettest-place-world-40-FEET-rain-year.html (accessed on 2 January 2022).

10. Shah. Sustainable Development of the Ganges-Brahmaputra-Meghna Basins-United Nations University. Available online: https://unu.edu/publications/books/sustainable-development-of-the-ganges-brahmaputra-meghna-basins.html (accessed on 12 March 2018).

11. Mirza, M.M.Q.; Warrick, R.A.; Ericksen, N.J. The Implications of Climate Change on Floods of the Ganges, Brahmaputra and Meghna Rivers in Bangladesh. Clim. Change 2003, 57, 287-318. [CrossRef]

12. Chowdhury, M.; Ward, N. Hydro-Meteorological Variability in the Greater Ganges-Brahmaputra-Meghna Basins. Int. J. Climatol. 2004, 24, 1495-1508. [CrossRef]

13. Kamal, R.; Matin, M.A.; Nasreen, S. Response of River Flow Regime to Various Climate Change Scenarios in Ganges-BrahmaputraMeghna Basin. J. Water Resour. Ocean Sci. 2013, 2, 15. [CrossRef]

14. Mohammed, K.; Islam, A.K.M.; Islam, T.; Alfieri, L.; Khan, M.J.U.; Bala, S.; Das, M. Future Floods in Bangladesh under $1.5^{\circ} \mathrm{C}, 2$ ${ }^{\circ} \mathrm{C}$, and $4{ }^{\circ} \mathrm{C}$ Global Warming Scenarios. J. Hydrol. Eng. 2018, 23, 04018050. [CrossRef]

15. Masood, M.; Yeh, P.J.-F.; Hanasaki, N.; Takeuchi, K. Model Study of the Impacts of Future Climate Change on the Hydrology of Ganges-Brahmaputra-Meghna Basin. Hydrol. Earth Syst. Sci. 2015, 19, 747-770. [CrossRef]

16. Masood, M.; Takeuchi, K. Climate Change Impacts and Its Implications on Future Water Resource Management in the Meghna Basin. Futures 2016, 78-79, 1-18. [CrossRef]

17. Masood, M.; Takeuchi, K. Climate Change Impact on the Manageability of Floods and Droughts of the Ganges-BrahmaputraMeghna Basins Using Flood Duration Curves and Drought Duration Curves. J. Disaster Res. 2015, 10, 991-1000. [CrossRef]

18. Merz, B.; Kreibich, H.; Schwarze, R.; Thieken, A. Review Article "Assessment of Economic Flood Damage". Nat. Hazards Earth Syst. Sci. 2010, 10, 1697-1724. [CrossRef]

19. Emanuelsson, M.A.E.; Mcintyre, N.; Hunt, C.; Mawle, R.; Kitson, J.; Voulvoulis, N. Flood Risk Assessment for Infrastructure Networks. J. Flood Risk Manag. 2014, 7, 31-41. [CrossRef]

20. Hasanzadeh Nafari, R.; Amadio, M.; Ngo, T.; Mysiak, J. Flood Loss Modelling with FLF-IT: A New Flood Loss Function for Italian Residential Structures. Nat. Hazards Earth Syst. Sci. 2017, 17, 1047-1059. [CrossRef]

21. Win, S.; Zin, W.W.; Kawasaki, A.; San, Z.M.L.T. Establishment of Flood Damage Function Models: A Case Study in the Bago River Basin, Myanmar. Int. J. Disaster Risk Reduct. 2018, 28, 688-700. [CrossRef]

22. Romali, N.; Sulaiman, S.; Yusop, Z.; Ismail, Z. Flood Damage Assessment: A Review of Flood Stage-Damage Function Curve. In ISFRAM 2014; Springer: Singapore, 2015. [CrossRef]

23. Olesen, L.; Löwe, R.; Arnbjerg-Nielsen, K. Flood Damage Assessment - Literature Review and Recommended Procedure; Cooperative Research Centre for Water Sensitive Cities: Melbourne, Australia, 2017.

24. Dutta, D.; Herath, S.; Musiake, K. A Mathematical Model for Flood Loss Estimation. J. Hydrol. 2003, 277, 24-49. [CrossRef]

25. Messner, F.; Meyer, V. Flood Damage, Vulnerability and Risk Perception-Challenges for Flood Damage Research; UFZ Discussion Papers; Helmholtz Centre for Environmental Research (UFZ), Division of Social Sciences (ÖKUS): Leipzig, Germany, 2005.

26. Foudi, S.; Oses-Eraso, N.; Tamayo, I. Integrated Spatial Flood Risk Assessment: The Case of Zaragoza. Land Use Policy 2015, 42, 278-292. [CrossRef]

27. Kefi, M.; Mishra, B.K.; Kumar, P.; Masago, Y.; Fukushi, K. Assessment of Tangible Direct Flood Damage Using a Spatial Analysis Approach under the Effects of Climate Change: Case Study in an Urban Watershed in Hanoi, Vietnam. ISPRS Int. J. Geo-Inf. 2018, 7, 29. [CrossRef] 
28. Khairul, I.M.; Mastrantonas, N.; Rasmy, M.; Koike, T.; Takeuchi, K. Inter-Comparison of Gauge-Corrected Global Satellite Rainfall Estimates and Their Applicability for Effective Water Resource Management in a Transboundary River Basin: The Case of the Meghna River Basin. Remote Sens. 2018, 10, 828. [CrossRef]

29. Okazumi, T.; Miyamoto, M.; Shrestha, B.B.; Gusyev, M. Uncertainty Estimation During the Process of Flood Risk Assessment in Developing Countries-Case Study in the Pampanga River Basin-. J. Disaster Res. 2014, 9, 69-77. [CrossRef]

30. Okazumi, T.; Tanaka, S.; Kwak, Y.; Shrestha, B.B.; Sugiura, A. Flood Vulnerability Assessment in the Light of Rice Cultivation Characteristics in Mekong River Flood Plain in Cambodia. Paddy Water Environ. 2014, 12, 275-286. [CrossRef]

31. Shrestha, B.B.; Okazumi, T.; Miyamoto, M.; Sawano, H. Flood Damage Assessment in the Pampanga River Basin of the Philippines. J. Flood Risk Manag. 2016, 9, 355-369. [CrossRef]

32. Jongman, B.; Hochrainer-Stigler, S.; Feyen, L.; Aerts, J.C.J.H.; Mechler, R.; Botzen, W.J.W.; Bouwer, L.M.; Pflug, G.; Rojas, R.; Ward, P.J. Increasing Stress on Disaster-Risk Finance Due to Large Floods. Nat. Clim. Change 2014, 4, 264-268. [CrossRef]

33. MOC. Outline of River Improvement Economic Research Investigation; Technical Report; River Engineering Bureau, Ministry of Construction (MOC): Tokyo, Japan, 1996.

34. MLIT. Ministry of Land, Infrastructure, Transport and Tourism. In Manual for Economic Analysis for Flood Control Projects; Publication of MLIT: Tokyo, Japan, 2005.

35. Zhai, G.; Fukuzono, T.; Ikeda, S. Modeling flood damage: Case of tokai flood 2000. J. Am. Water Resour. Assoc. 2005, 41, 77-92. [CrossRef]

36. Velasco, M.; Cabello, À.; Russo, B. Flood Damage Assessment in Urban Areas. Application to the Raval District of Barcelona Using Synthetic Depth Damage Curves. Urban Water J. 2016, 13, 426-440. [CrossRef]

37. Shrestha, B.B.; Kawasaki, A.; Zin, W.W. Development of Flood Damage Functions for Agricultural Crops and Their Applicability in Regions of Asia. J. Hydrol. Reg. Stud. 2021, 36, 100872. [CrossRef]

38. Win, S.; Zin, W.W.; Kawasaki, A. Development of Flood Damage Estimation Model for Agriculture - Case Study in the Bago Floodplain, Myanmar. J. Disaster Res. 2020, 15, 242-255. [CrossRef]

39. Scorzini, A.R.; Di Bacco, M.; Manella, G. Regional Flood Risk Analysis for Agricultural Crops: Insights from the Implementation of AGRIDE-c in Central Italy. Int. J. Disaster Risk Reduct. 2021, 53, 101999. [CrossRef]

40. Tingsanchali, T.; Karim, M.F. Flood Hazard and Risk Analysis in the Southwest Region of Bangladesh. Hydrol. Processes 2005, 19, 2055-2069. [CrossRef]

41. Khan, D.; Rahman, S.; Haque, A.K.; Chen, A.; Hammond, M.; Djordjević, S.; Butler, D. Flood Damage Assessment for Dhaka City, Bangladesh. In Proceedings of the 2nd European Conference on Flood Risk Management: Science, Policy and Practice: Closing the Gap, Rotterdam, The Netherlands, 20-22 November 2012.

42. Masood, M.; Takeuchi, K. Assessment of Flood Hazard, Vulnerability and Risk of Mid-Eastern Dhaka Using DEM and 1D Hydrodynamic Model. Nat. Hazards 2012, 61, 757-770. [CrossRef]

43. Hussain, S. Decision Support System for Assessing Rice Yield Losses from Annual Flooding in Bangladesh. Ph.D. Thesis, University of Hawhaii, Manoa, HI, USA, 1995.

44. Gain, A.K.; Hoque, M.M. Flood Risk Assessment and Its Application in the Eastern Part of Dhaka City, Bangladesh. J. Flood Risk Manag. 2013, 6, 219-228. [CrossRef]

45. Gain, A.K.; Mojtahed, V.; Biscaro, C.; Balbi, S.; Giupponi, C. An Integrated Approach of Flood Risk Assessment in the Eastern Part of Dhaka City. Nat. Hazards 2015, 79, 1499-1530. [CrossRef]

46. Lehner, B.; Verdin, K.; Jarvis, A. New Global Hydrography Derived from Spaceborne Elevation Data. Eos Trans. Am. Geophys. Union 2008, 89, 2. [CrossRef]

47. Tateishi, R.; Hoan, N.T.; Kobayashi, T.; Alsaaideh, B.; Tana, G.; Phong, D.X. Production of Global Land Cover DataGLCNMO2008. J. Geogr. Geol. 2014, 6, 99. [CrossRef]

48. DDM. Reports of Department of Disaster Management (DDM), Bangladesh on Damage Information and Relief Distribution on Flash Flood: Situation Update. 4 May 2017. Available online: https:/ /Reliefweb.Int/Sites/Reliefweb.Int/Files/Resources/ Flash\%20Flood\%20Report\%20With\%20Updated\%20Map_MAY\%2004\%2C\%202017.Pdf (accessed on 10 January 2022).

49. Chakraborty, D.; Mondal, K.P.; Islam, S.; Roy, J. 2017 Flash Flood in Bangladesh: Lessons Learnt. In Disaster Resilience and Sustainability; Elsevier: Amsterdam, The Netherlands, 2021; pp. 591-610. ISBN 978-0-323-85195-4.

50. BBS. Statistical Year Book of Bangladesh (31st and 37th Edition); Bangladesh Bureau of Statistics (BBS) 2011. 2017. Available online: http://Www.Bbs.Gov.Bd/Site/Page/29855dc1-F2b4-4dc0-9073-F692361112da/Statistical-Yearbook (accessed on 10 January 2022).

51. Taherdoost, H. Sampling Methods in Research Methodology; How to Choose a Sampling Technique for Research. Int. J. Acad. Res. Manag. 2016, 5, 18-27. [CrossRef]

52. Seshadhri, G.; Topkar, V.M. Validation of a Questionnaire for Objective Evaluation of Performance of Built Facilities. Int. J. Earth Sci. Eng. 2015, 8, 972-976. [CrossRef]

53. FAO. Country Fact Sheet on Food and Agriculture Policy Trends-United Republic of Tanzania; FAO: Rome, Italy, 2016.

54. Islam, M. Crop Calendar Mapping of Bangladesh Rice Paddy Field with ALOS-2 ScanSAR Data. Adv. Remote Sens. 2021, 10, 115-129. [CrossRef]

55. Kreibich, H.; Seifert, I.; Merz, B.; Thieken, A.H. Development of FLEMOcs-A New Model for the Estimation of Flood Losses in the Commercial Sector. Hydrol. Sci. J. 2010, 55, 1302-1314. [CrossRef] 
56. Grahn, T.; Nyberg, L. Assessment of Pluvial Flood Exposure and Vulnerability of Residential Areas. Int. J. Disaster Risk Reduct. 2017, 21, 367-375. [CrossRef]

57. Sayama, T.; Ozawa, G.; Kawakami, T.; Nabesaka, S.; Fukami, K. Rainfall-Runoff-Inundation Analysis of the 2010 Pakistan Flood in the Kabul River Basin. Hydrol. Sci. J. 2012, 57, 298-312. [CrossRef]

58. Sayama, T.; Tatebe, Y.; Iwami, Y.; Tanaka, S. Hydrologic Sensitivity of Flood Runoff and Inundation: 2011 Thailand Floods in the Chao Phraya River Basin. Nat. Hazards Earth Syst. Sci. 2015, 15, 1617-1630. [CrossRef]

59. Gumma, K.M.; Nelson, A.; Thenkabail, P.S.; Singh, A.N. Mapping Rice Areas of South Asia Using MODIS Multitemporal Data. J. Appl. Remote Sens. 2011, 5, 053547. [CrossRef]

60. Recanatesi, F.; Petroselli, A. Land Cover Change and Flood Risk in a Peri-Urban Environment of the Metropolitan Area of Rome (Italy). Water Resour. Manag. 2020, 34, 4399-4413. [CrossRef]

61. Pellicani, R.; Parisi, A.; Iemmolo, G.; Apollonio, C. Economic Risk Evaluation in Urban Flooding and Instability-Prone Areas: The Case Study of San Giovanni Rotondo (Southern Italy). Geosciences 2018, 8, 112. [CrossRef]

62. Rajib, A.; Zheng, Q.; Golden, H.; Wu, Q.; Lane, C.; Christensen, J.; Morrison, R.; Annis, A.; Nardi, F. The Changing Face of Floodplains in the Mississippi River Basin Detected by a 60-Year Land Use Change Dataset. Sci. Med. Data 2021, 8, 271. [CrossRef]

63. DAE. Field Reports on Boro Rice Damage in 2017 Haor Flash Floods, Generated by Department of Agricultural Extension (DAE), Bangladesh, Collected during Field Survey. Sunamganj and Sylhet, Bangladesh; DAE: Dhaka, Bangladesh, 2017.

64. Kamal, A.S.M.M.; Shamsudduha, M.; Ahmed, B.; Hassan, S.M.K.; Islam, M.S.; Kelman, I.; Fordham, M. Resilience to Flash Floods in Wetland Communities of Northeastern Bangladesh. Int. J. Disaster Risk Reduct. 2018, 31, 478-488. [CrossRef]

65. Pivot, J.M.; Josien, E.; Martin, P. Farms Adaptations to Changes in Flood Risk: A Management Approach. J. Hydrol. 2002, 267, 12-25. [CrossRef]

66. Morris, J.; Brewin, P. The Impact of Seasonal Flooding on Agriculture: The Spring 2012 Floods in Somerset, England. J. Flood Risk Manag. 2014, 7, 128-140. [CrossRef]

67. Molinari, D.; Scorzini, A.R.; Gallazzi, A.; Ballio, F. AGRIDE-c, a Conceptual Model for the Estimation of Flood Damage to Crops: Development and Implementation. Nat. Hazards Earth Syst. Sci. 2019, 19, 2565-2582. [CrossRef] 